\title{
ARTICLES
}

\section{Compensatory Constitutionalism: The Function and Potential of Fundamental International Norms and Structures}

\author{
ANNE PETERS*
}

\begin{abstract}
The article conceives international (or global) constitutionalism as a legal argument which recommends and strengthens efforts (legal and political) to compensate for ongoing deconstitutionalization on the domestic level. Although the notions 'international constitution' and 'international constitutionalism' have in recent years served as buzzwords in various discourses, the many meanings of those concepts have not yet been fully explored and disentangled. This paper suggests a specific understanding of those concepts. It highlights various aspects and elements of micro- and macro-constitutionalization in international law, and identifies anti-constitutionalist trends. On this basis, the paper finds that, although no international constitution in a formal sense exists, fundamental norms in the international legal order do fulfil constitutional functions. Because those norms can reasonably be qualified as having a constitutional quality, they may not be summarily discarded in the event of a conflict with domestic constitutional law. Because the relevant norms form a transnational constitutional network, and cannot be aligned in an abstract hierarchy, conflict resolution requires a balancing of interests in concrete cases. Finally, because constitutionalism historically and prescriptively means asking for a legitimate constitution, a constitutionalist reading of the international legal order provokes the question of its legitimacy. This question is pressing, because state sovereignty and consent are - on good grounds - no longer accepted as the sole source of legitimacy of international law. International constitutionalism - as understood in this paper-does not ask for state-like forms of legitimacy of a world government, but stimulates the search for new mechanisms to strengthen the legitimacy of global governance.
\end{abstract}

\section{Key words}

constitution; constitutionalism; legitimacy; global governance; democracy; rule of law

* $\quad$ Dr. iur., LL.M. (Harvard); Professor of Public International Law and Constitutional Law at the University of Basel. This article forms part of a research project, 'Constitutionalism and Multilayered Governance', within the Swiss National Centre of Competence in Research 'International Trade Law: From Fragmentation to Coherence', funded by the Swiss National Science Foundation. It builds on a presentation at a seminar on 'The Future of International Constitutional Law', held in Amsterdam in November 2003, which formed part of the research project 'Interactions between International Law and National Law', funded by the Netherlands Organization for Scientific Research. Some of it relies on parts taken from my 'Global Constitutionalism in a Nutshell', in K. Dicke et al. (eds.), Weltinnenrecht (2005), 535-50. I thank Jan Klabbers, Nikolas Stürchler, Egle Svilpaite, and Geir Ulfstein for comments on the draft. 


\section{THE THESIS: DOMESTIC DE-CONSTITUTIONALIZATION DUE TO GLOBALIZATION SHOULD AND COULD BE COMPENSATED FOR BY THE CONSTITUTIONALIZATION OF INTERNATIONAL LAW}

My basic proposition is that the old idea of an international constitution of the international legal community ${ }^{\mathrm{I}}$ deserves reconsideration in the light of globalization. This proposition can build on the work of scholars who have been arguing that the structure of international law has generally evolved from coexistence via cooperation (à la Wolfgang Friedman) to constitutionalization. ${ }^{2}$

In the era of globalization, a constitutionalist reconstruction is a desirable reaction to visible de-constitutionalization on the domestic level. The phenomenon of globalization, that is, the appearance of global, de-territorialized problems and the emergence of global networks in the fields of economy, science, politics, and law, has increased global interdependence. Globalization puts the state and state constitutions under strain: global problems compel states to co-operate within international organizations and through bilateral and multilateral treaties. Previously, typically governmental functions, such as guaranteeing human security, freedom, and equality, are in part transferred to 'higher' levels. Moreover, non-state actors (acting within states or even in a transboundary fashion) are increasingly entrusted with the exercise of traditional state functions, even with core tasks such as military and police activity. ${ }^{3}$ The result of these multiple phenomena is that 'governance' (understood as the overall process of regulating and ordering issues of public interest $\left.{ }^{4}\right)$ is exercised beyond the states' constitutional confines. This means that state constitutions can no longer regulate the totality of governance in a comprehensive way, and the state constitutions' original claim to form a complete basic order is thereby defeated. The hollowing out of national constitutions affects not only the constitutional principle of democracy, but also the rule of law and the principle of social security. Overall, state constitutions are no longer 'total constitutions'. In consequence, we should ask for compensatory constitutionalization on the international plane. Only the various levels of governance, taken together, can provide full constitutional protection. ${ }^{5}$

I. See, seminally, A. Verdross, Die Verfassung der Völkerrechtsgemeinschaft (I926), Preface.

2. See for an excellent and critical historical overview of the various 'schools' and lines of thought describing and/or propagating an international constitution and constitutionalization H. Ruiz Fabri and C. Grewe, 'La constitutionnalisation à l'épreuve du droit international et du droit européen', in L. Gard et al. (eds.), Les dynamiques du droit européen en début de siècle, Etudes en l'honneur de Jean-Claude Gautron (2004), at I89-206. See for important recent articulations, albeit in very different perspectives, J. Habermas, 'Hat die Konstitutionalisierung des Völkerrechts noch eine Chance?’, in J. Habermas, Der gespaltene Westen: Kleine politische Schriften (2004), II3-93; E. de Wet, 'The International Constitutional Order', (2006) 55 ICLQ 5 I-76; R. MacDonald and D. Johnston (eds.), Towards World Constitutionalism: Issues in the Legal Ordering of the World Community (2005).

3. In US-occupied Iraq of 2003-4, employees of federal contractors and sub-contractors (Blackwater USA, Kroll Inc., Custer Battles, the Titan corporation, and others) worked as mercenaries, police, guards, prison officers, and interrogators.

4. J. N. Rosenau, 'Governance, Order, and Change in World Politics', in J. N. Rosenau and E.-O. Czempiel (eds.), Governance Without Government (I992) I, at 7: 'Governance', as opposed to 'government', does not stem from some overarching governmental authority. See also Commission on Global Governance, Our Global Neighbourhood: The Report of the Commission on Global Governance (I995).

5. This is the central argument of T. Cottier and M. Hertig, 'The Prospects of 2 Ist Century Constitutionalism', (2003) 7 Max Planck Yearbook of United Nations Law 26I-328. See in this sense also the recent Resolution of the 


\section{SOME WORKING DEFINITIONS: 'CONSTITUTION', 'CONSTITUTIONALIZATION', AND 'CONSTITUTIONALISM'}

In order to identify a constitution within international law and to discern elements of global constitutionalism, we must first clarify the notions of 'constitution', 'constitutional law', 'constitutionalization', and finally 'constitutionalism'. This is all the more important since all these terms have many meanings, are employed by different authors in very different senses, and consequently contribute to confusions in the current debates.

'Constitution' is an ambiguous concept, ${ }^{6}$ whose various (contested) elements will be explored below (section 3). At the outset, it is important to note that this paper deals with 'constitution' in a normative sense only. We are not concerned here with 'constitution' as a descriptive term, in the sense of 'Amsterdam is constituted by little canals'. We may take it as a positive omen that the first modern and still accepted definition of constitution (in a normative sense) was given not in a treatise on domestic law, but by an international lawyer in a book on the law of nations. Writing in 1758 , Emer de Vattel explained that 'le règlement fondamental qui détermine la manière dont l'Autorité Publique doit être exercée est ce qui forme la Constitution de l'Etat'. Relying on this (rather broad) definition, this paper assumes that a constitution (in a normative sense) is the sum of basic (materially most important) legal norms which comprehensively regulate the social and political life of a polity. 'Constitutional law' is not quite synonymous, because this term is somewhat less than the term 'constitution' associated with a written document. ${ }^{8}$ The term 'constitution' has a positive appeal which is owed to the positive connotations of a legitimate constitution as a good order (although there may also be illegitimate constitutions).

Constitutions have historically been closely linked to states. Some observers even contrasted the constitutional idea with the (ostensibly anti-constitutional) international sphere. ${ }^{9}$ However, the term 'constitution' was never exclusively reserved for state constitutions. Today, the notional link between constitution and state has further been loosened in everyday language and in the legal discourse (and thereby the meaning of 'constitution' may have been broadened). It is therefore not per definitionem impossible to conceptualize constitutional law beyond the nation or the state.

UN General Assembly on the 2005 World Summit Outcome, recognizing 'the need for universal adherence to and implementation of the rule of law at both the national and international level'. UN Doc. A/RES/60/I of 24 Oct. 2005 , para. 134 (emphasis added).

6. See for excellent historical and lexical accounts in different national traditions: H. Mohnhaupt and D. Grimm, Verfassung. Zur Geschichte des Begriffs von der Antike bis zur Gegenwart (I995); U. K. Preuss, 'Verfassung', in J. Ritter (ed.), Historisches Wörterbuch der Philosophie, Vol. I I (200 I), at 635-43; O. Beaud, 'Constitution et constitutionnalisme', in P. Raynaud and S. Rials (eds.), Dictionnaire de philosophie politique (2003), at I33-42. See also A. Peters, Elemente einer Theorie der Verfassung Europas (2001), at 38-92.

7. E. de Vattel, Le droit des gens ou principes de la loi naturelle appliqués à la conduite et aux affaires de Nations et des Souverains (I758, repr. I9I6), book I, chap. III, $\S 27$ (at 3I).

8. See D. Fellmann, 'Constitutional Law', in Encyclopedia Britannica, Vol. 5 (I980), 84 et seq.

9. État ou barbarie, telle est l'alternative simple que connaît la société internationale.' S. Sur, 'L'état entre éclatement et mondialisation', (I997) 30 Revue belge de droit international 5, at I I. 
Based on the preceding preliminary reflections, we may formulate as a working hypothesis that 'global (or international) constitutional law' is the bulk of the most important norms which regulate political activity and relationships in the global polity (consisting of states and other subjects of international law). It is a subset of international rules and principles which are so important that they deserve the label 'constitution'. Whether these norms (rules and principles) of potential constitutional quality are superior to ordinary international norms, whether they are codified in one or several documents, whether they are created by states or by other actors as well, whether they are always 'hard' legal norms, whether they embody a specific set of material principles, and whether they are 'constitutional' only to the extent that they are enforceable by some form of judicial review, remains to be seen.

'Constitutionalization' is shorthand for the emergence of constitutional law within a given legal order. The concept of constitutionalization implies that a constitution (or constitutional law) can come into being in a process extended through time. It also implies that a legal text (or various legal texts) can acquire (or eventually lose) constitutional properties in a positive feedback process. A text can therefore be more (or less) constitution-like. It may be, in short, a constitution-in-the-making. In consequence, 'global (or international) constitutionalization' is used in this paper as a catchword for the continuing process of the emergence, creation, and identification of constitution-like elements in the international legal order. ${ }^{\text {Io }}$

Another important term in our context is 'constitutionalism'. ${ }^{\text {I I }}$ Historically, 'constitutionalism', was the political movement of the seventeenth and eighteenth centuries in quest of a written constitution (of the nation state). The basic purpose of the constitution was to subdue political power (the prince) to the law, hence to create a government of laws, not of men. In order to reach that objective the constitution was to embody certain material principles, most importantly the separation of powers, or checks and balances. It is important to realize that the concept of 'constitutionalism' is more than the term 'constitution' (which is in that respect more ambiguous) loaded with material contents. 'Constitutionalism does not refer simply to having a constitution, but to having a particular kind of constitution, however difficult it may be to specify its contents.' ${ }^{\text {22 }}$ Until today, 'constitutionalism' has - as a prescriptive

Io. Beyond the purely domestic context, the term 'constitutionalization' was coined with regard to the EC/EU. See, seminally, 'The Constitutionalization of the Treaty of Rome', G. Casper, 'Remarks', in American Society of International Law (ed.), Proceedings of the 72-d Annual Meeting (I978) I69, at I73.

II. See G. Casper, 'Constitutionalism', in L. W. Levy, K. L. Karst, and D. J. Mahoney (eds.), Encyclopedia of the American Constitution, Vol. 2 (I986), at 473-80; U. K. Preuss, 'Constitutionalism', in E. Craig (ed.), Routledge Encyclopedia of Philosophy, Vol. 2 (I998), 6I 8 et seq.; Red., 'Konstitutionalismus', in J. Ritter (ed.), Historisches Wörterbuch der Philosophie, Vol. 4 (I989), at 1005; Beaud, supra note 6, at I33 et seq.

I2. Casper, supra note I I, at 474. J. H. Weiler and M. Wind have correctly pointed out that 'there is a difference between constitution and constitutionalism. Constitutionalism ... embodies the values, often non-stated, which underlie the material and institutional provisions in a specific constitution. At this level, separating constitution from constitutionalism would allow us to claim, rightly or wrongly, for example, that the Italian and German constitutions, whilst very different in their material and institutional provisions, share a similar constitutionalism vindicating certain neo-Kantian humanistic values, combined with the notion of the Rechtsstaat' (J. H. Weiler and M. Wind, 'Introduction', in J. H. Weiler and M. Wind (eds.), European Constitutionalism Beyond the State (2003) I, at 3). See extensively on the 'divorce' of constitution and constitutionalism Beaud, supra note 6, at $136-42$. 
term - basically retained the meaning sketched out above. It is associated with rule of law and with containment, sometimes even with judicial review and eventually with constitutional courts. ${ }^{\mathrm{I} 3}$

Jed Rubenfeld has argued that two diverging conceptions of constitutionalism, namely a genuinely ‘European' one and a different 'American' one, exist. In that view, 'international constitutionalism' is a genuinely European conception. In contrast, the (supposedly) American 'democratic national constitutionalism' regards constitutional law 'as the embodiment of a particular nation's democratically self-given legal and political commitments'. ${ }^{\text {I4 }}$ However, the ostensibly genuinely 'American' claim that international constitutional law is irreconcilable with domestic democratic mechanisms and popular sovereignty has been intensely and painfully discussed in Europe with a view to the EU constitution, notably by German jurists. ${ }^{15}$ So the controversy around this tension is not a debate between national-constitutional cultures, but a cross-cutting one between diverging, but transnational, ideologies. Moreover, I can find no logical or constructive reasons why US constitutional theory cannot - unlike European constitutionalism - accept the idea of containment by international law. If the asserted specifically American outlook on constitutionalism does indeed exist (which is, as just pointed out, doubtful), it is simply due to the bad habits of a government which is powerful enough to have its way. So we can safely rely on the (more abstract) core of both the 'European' conception of constitutionalism (Britain and France being the mother countries of constitutionalism) and the 'American' conception. This is the idea that some (superior ${ }^{16}$ ) law exists which confines government. ${ }^{17}$ Constitutionalism implies, in short, government (and also governance) under law.

Building on this transnational consensus, I employ the term 'global (or international) constitutionalism' in order to characterize a strand of thought (an outlook or perspective) and a political agenda which advocate the application of constitutional principles, such as the rule of law, checks and balances, human rights protection, and democracy, in the international legal sphere in order to improve the effectivity and the fairness of the international legal order. ${ }^{18}$ Global constitutionalism is, in

I3. See B. Ackerman, 'The Rise of World Constitutionalism', (I997) 83 Virginia Law Review 77 I-97.

I4. J. Rubenfeld, 'The Two World Orders', (2003) 27 Wilson Quarterly 28 et seq. See also the contributions in G. Nolte (ed.), American and European Constitutionalism (2005).

I5. See, seminally, D. Grimm, 'Braucht Europa eine Verfassung?', (I 995) 50 Juristen-Zeitung 58I et seq.

I6. A higher rank is not incumbent on the British Constitution; see section 3.I.

I7. See for the US view J. Madison, 'No. 5I', in The Federalist Papers, ed. Clinton Rossiter (I96I [I788]), at 322: 'In framing a government which is to be administered by men over men, the great difficulty lies in this: you must first enable the government to control the governed and in the next place, oblige it to control itself. A dependence on the people is, no doubt, the primary control of government; but experience has taught mankind the necessity of auxiliary precautions.' See for a German view the classic work by W. von Humboldt, Ideen zu einem Versuch, die Grenzen der Wirksamkeit des Staates zu bestimmen (1792). See for French constitutionalism Beaud, supra note 6, at 136 .

I8. Cf. B. Fassbender, 'The United Nations Charter as Constitution of the International Community', (I998) 36 Columbia Journal of Transnational Law 529, at 552: 'the concept [of constitutionalism] is meant to describe or promote a legal integration of states which is more intense than the traditional one.... International constitutionalism is a progressive movement which aims at fostering international cooperation by consolidating the substantive legal ties between states as well as the organizational structures built in the past.' 
the words of Richard Falk, "[t]he extension of constitutionalist thinking to world order'. ${ }^{\text {I9 }}$

After these terminological clarifications, we shall proceed first to identify formal and material elements and functions of domestic constitutional law (section 3), and then describe and relate international and transnational 'constitutionalization' to these elements (sections 4 to 6).

\section{A Closer look at state constitutions}

\section{I. Formal elements of state constitutions}

State constitutions are normally said to have typical formal characteristics. One is that they are codified in one document. 'La constitution, à l'origine, est d'abord un acte écrit.' ${ }^{20}$ Writtenness is an essential element of the modern, North American and continental notion of constitution. The quest for a constitutional charter was the primordial objective of the constitutionalist movement in the United States, last but not least in reaction to the British Constitution, which the American colonists deemed arbitrary and unjust. The British Constitution consisted and still consists, as is well known, of various charters, bills, judicial pronouncements, and constitutional conventions. It is therefore in part an 'unwritten' constitution.

The second traditional formal property of constitutional law is that it supersedes ordinary law. The technical device to secure the constitution's superiority is a special amending procedure which shields the constitution from modification through ordinary legislation. Again, the British Constitution is an exception, because the English parliament has, by virtue of parliamentary sovereignty, the power to make and amend laws of a constitutional quality in the ordinary legislative procedure. The British Constitution is therefore a 'flexible' as opposed to a 'rigid' constitution in terms of the distinction established by James Bryce. ${ }^{2 \mathrm{I}}$ The Constitution of the German Empire (I87 I-I9I8) was also a 'flexible' constitution without special sanctity. ${ }^{22}$

The third formal feature of codified constitutions is that they are made by a pouvoir constituant in a kind of constitutional big bang. The most influential theorists of the

I9. R. Falk, 'The Pathways of Global Constitutionalism', in R. Falk et al. (eds.), The Constitutional Foundations of World Peace(I993) I3, at I 4. 'This outlook is based on both will (or desire) and interest (or necessity) [to achieve] a more institutionalized (although not necessarily more centralized) form of governance that avoids war in conflict situations and works towards a world in which the well-being of all is safeguarded by enforceable rights, and the environment is protected on behalf of future generations as well as those now alive.... "Global constitutionalism” as used here, is itself a manifestation of global civil society in a nascent form' (ibid., emphasis added). See also J.H. Jackson, 'Changing Fundamentals of International Law and International Economic Law', (2003) 4I Archiv des Völkerrechts 435, at 447: 'We are going to need a new constitutionalism of institutions.'

20. D. Rousseau, 'Une résurrection: La notion de Constitution', (1990) Io6 Revue du droit public et de la science politique en France et l'étranger 5 .

21. Flexible constitutions 'proceed from the same authorities which make the ordinary laws; and they are promulgated or repealed in the same way as ordinary laws.' In a polity with a flexible constitution, 'all laws (excluding of course by-laws, municipal regulations, and so forth) are of the same rank and exert the same force. There is, moreover, only one legislative authority competent to pass laws in all cases and for all purposes.' In contrast, 'the distinctive mark of these Rigid Constitutions is their superiority to ordinary statutes. They are not the work of the ordinary legislature, and therefore cannot be changed by it.' (J. Bryce, 'Essay III: Flexible and Rigid Constitutions', in J. Bryce, Studies in History and Jurisprudence, Vol. I (I 9o I, repr. I980), at I50-I and 2I7-I8).

22. G. Meyer and G. Anschütz, Lehrbuch des Deutschen Staatsrechts (I9I4-I9), at 743-4. 
pouvoir constituant, the French revolutionist Abbé Sieyès ${ }^{23}$ and the German jurist Carl Schmitt, ${ }^{24}$ formulated their conceptions with a view to the political revolutions of their time, which brought into being new constitutions abruptly, and accompanied by upheaval, chaos, and violence (I789 in France, I 91 8 in Germany). Again, we have the exception of England, whose constitutional law continuously evolved through centuries. And of course it is widely acknowledged that constitutions are living instruments ${ }^{25}$ which are more or less silently modified and transformed through judicial and political practice. ${ }^{26}$

\subsection{Traditional functions and substantial properties of state constitutions}

The substantial components of a 'constitution' are even more contested. There are at least three answers to the following question: Which functions and contents must be present to call a given body of law a 'constitution' (or at least 'constitutional law')? The broadest notion of constitution refers to the bulk of laws organizing and institutionalizing a polity. International law is currently in a state of some organization and institutionalization. Therefore we have an international constitution in this broadest sense.

The narrower, functional notion of constitution relates to rules and principles fulfilling typical constitutional functions. The traditional constitutional functions are to constitute a political entity as a legal entity, to organize it, to limit political power, to offer political and moral guidelines, to justify governance, and, finally, to contribute to integration. ${ }^{27}$

The third and narrowest notion, which I should like to call a legitimist notion of a constitution, is the one underlying eighteenth- and nineteenth-century constitutionalism. It has been enunciated most famously in Article I6 of the French Declaration of the Rights of Man and Citizen of 26 August I789: 'Toute societé dans laquelle la garantie des droits n’est pas assurée, ni la séparation des pouvoirs déterminée, n’a point de constitution.' Human rights and the separation of powers are the necessary elements of a constitution. Nowadays, further material elements have been added, most importantly democracy and a minimum of social security guarantees. From this perspective, 'constitution' is a value-laden concept.

\section{DifFERENT PHENOMENA OF CONSTITUTIONALIZATION OF INTERNATIONAL LAW}

Against the background of what has usually (on the domestic plane) been called a 'constitution' in the functional or the legitimist sense just explained, we shall

\footnotetext{
23. A. Sieyès, Qu'est-ce qu'est le tiers état? (I789).

24. C. Schmitt, Verfassungslehre (I928), at 75-6.

25. A constitutional act calls 'into life a being the development of which could not have been foreseen completely by the most gifted of its begetters.' Justice O. Wendell Holmes, in Missouri v. Holland, 252 U.S. 4I6, 433 (I9I9).

26. The most important German theorists holding this view are R. Smend, 'Verfassung und Verfassungsrecht', in R. Smend, Staatsrechtliche Abhandlungen (I994), at I92-3 (orig. I928); P. Häberle, 'Verfassungsinterpretation und Verfassunggebung', in P. Häberle, Verfassung als öffentlicher Prozeß: Materialien zu einer Verfassungstheorie der offenen Gesellschaft (I 978) I 82-224; and F. Müller, Fragment (über) verfassunggebende Gewalt des Volkes (I 995 , manuscript of $1967 / 68)$, at I5, 22, 34 .

27. See extensively Peters, supra note 6 , at 76 et seq.
} 
in the next step approach the subject from the opposite side and look at those phenomena discussed under the heading of 'constitutionalization of international law'. We should then be able to judge to what extent this heading is justified.

\section{I. New bases of legitimacy of international law}

The basic premise of the constitutionalist school is that the international community is a legal community. ${ }^{28} \mathrm{~A}$ legal community is governed by rules and principles, not (only) by power. The most fundamental norms might represent global constitutional law. Starting from this point, constitutionalists discern and support the emergence of new bases of legitimacy for the international legal system; the traditional legitimating factors of international governance are state sovereignty and the effective exercise of power. Therefore, international law used to be blind to constitutional principles within states. In contrast, the idea of constitutionalism implies that state sovereignty is gradually being complemented (not substituted) by other guiding principles, notably the respect for human rights, ${ }^{29}$ human dignity, ${ }^{30}$ 'human security',31 a 'principle of civil inviolability',32 and/or the 'global common interest' and/or 'rule of law'. Because state sovereignty remains important as a shield against intervention by great powers, it does not further the cause of constitutionalism to strive for the establishment of a new 'foundational norm' which would replace sovereignty. ${ }^{33}$ However, the concept of state sovereignty is undergoing important modifications, ${ }^{34}$ and respect for sovereignty is being linked to respect for human rights. ${ }^{35}$ How these links should be guaranteed in practice (in particular whether in extreme cases by military means 'humanitarian intervention') requires further exploration. Despite these open and hard questions, it can hardly be denied that the international legal order is in the process of shifting from an order based on 'Westphalian sovereignty'36 (conceived as carte blanche for national governments

28. See for references to the 'international community as a whole', Case Concerning the Barcelona Traction, Light and Power Company, Limited (second phase), [I970] ICJ Rep. 3, para. 33; ICC Statute of I7 July I998 (UNTS Vol. 2 I 87, No. 38544), Preamble, para. 4, and ILC Articles on state responsibility (200I), Doc. A/CN.4/L.602, Rev. I, Art. 42(b). See in scholarship A. Paulus, Die internationale Gemeinschaft im Völkerrecht (200I), Eng. summary at 439 et seq.

29. See, e.g., Habermas, supranote 2, at I 23, relying on I. Kant; B.-O. Bryde, 'Konstitutionalisierung des Völkerrechts und Internationalisierung des Verfassungsrechts', (2003) 42 Der Staat 6I, at 64-6; A. Buchanan, Justice, Legitimacy, and Self-Determination: Moral Foundations for International Law (2004) passim, e.g. at 290.

30. E.g. D. Thürer, 'Von der komplexen Gestalt des Völkerrechts,' in J. Bröhmer et al. (eds.), Internationale Gemeinschaft und Menschenrechte (2005), 307, at 3I 2.

3I. See International Commission on Intervention and State Sovereignty (ICISS), The Responsibility to Protect (200I), I4-I8, available at http://www.dfait-maeci.gc.ca/iciss-ciise/pdf/Commission-Report.pdf (last visited 28 Aug. 2005).

32. A.-M. Slaughter and W. Burke-White, 'An International Constitutional Moment', (2002) 43 Harvard International Law Journal I, esp. at 2-3 (suggesting that besides the prohibition of the use of force between states is established a provision prohibiting the use of force by civilians against civilians as 'parallel prohibitions that are the twin foundations of international order').

33. B. Kingsbury, 'Sovereignty and Inequality', (I998) 9 EJIL 599-625; J. L. Cohen, 'Whose Sovereignty? Empire versus International Law', (2004) I 28 Ethics \& International Affairs I-24.

34. S. D. Krasner, Sovereignty: Organized Hypocrisy (I 999); N. Schrijver, 'The Changing Nature of State Sovereignty', (I999) 70 BYIL 65-98.

35. See ICISS, supra note 3I; J. P. Müller, 'Wandel des Souveränitätsbegriffs im Lichte der Grundrechte', in R. Rhinow, S. Breitenmoser, and B. Ehrenzeller (eds.), Fragen des internationalen und nationalen Menschenrechtsschutzes (I997), 45, at 6I-6.

36. Krasner, supra note 34. 
to organize their domestic legal and political structures without any authoritative external interference) to a 'hybrid' or 'dualistic' world order, based on (modified) state sovereignty and the autonomy or self-determination of the individual. ${ }^{37}$ The principle of state sovereignty no longer serves as the exclusive source of legitimacy of international norms (and is, from a normative standpoint, increasingly contested as a legitimizing factor in itself).

\subsection{International law making: the erosion of the consent requirement}

The current shift of the justificatory basis of international law manifests itself in a number of legal developments on the international plane. The first cross-cutting phenomenon is the erosion of the consent requirement. ${ }^{38}$ In customary law, the weakening of the persistent-objector rule is the relevant legal trend. ${ }^{39}$ In the law of international institutions, the practice of majority voting in organs of international organizations and treaty bodies (and the ensuing obligation of 'defeated' states to comply with these decisions) points in this direction as well. These areas of law will be left aside here. In the following, I shall focus on the law of treaties only.

Certain types of international legal acts and their outcomes (be it objective regimes, world-order treaties, or legislation by the Security Council) have 'third-party effects. ${ }^{40}$ Already Hans Kelsen has observed that

The restriction of the personal sphere of validity of contractual norms establishing obligations ... is the consequence of the principle of the sovereignty of the state, which - as it is usually understood - implies that a state cannot be legally bound without its consent. It is, however, a characteristic tendency of modern international law to restrict this principle. Treaties imposing obligations upon third states have been generally recognized in a steadily increasing measure. ${ }^{4 \mathrm{I}}$

For example, Article 2(6) of the UN Charter foresees that the United Nations 'shall ensure that states which are not members of the United Nations act in accordance with these principles so far as may be necessary for the maintenance of international peace and security'. Moreover, it is often assumed that international treaties on territories may create 'objective regimes'. ${ }^{42}$ Such 'status treaties' have secured the

37. Cf. Art. I-I of the Treaty Establishing a Constitution for Europe of 29 October 2004, which begins with the formula: 'Reflecting the will of the citizens and States of Europe to build a common future, this Constitution establishes the European Union,...' (OJ 2004 C 3IO/I). See in scholarship on the dual foundation of the global legal order Habermas, supra note 2, at I33; Cohen, supra note 33, at I3. Arguably, this dual foundation is still lopsided in the sense that the state sovereignty pillar is the load-bearing one.

38. C. Tomuschat, 'Obligations Arising for States Without or Against Their Will', (I993) 24I-IV Recueil des cours 209-40.

39. J. Charney, 'The Persistent Objector Rule and the Development of Customary International Law', (I986) 56 BYIL I-24.

40. See comprehensively for the law of treaties with numerous examples G. Dahm, J. Delbrück and R. Wolfrum, Völkerrecht, Vol. I/3 (2002), at 6I3-32 ( 152 on 'Verträge zugunsten und zu Lasten Dritter; insbesondere Verträge mit erga omnes Wirkung'). But see critically M. A. Fitzmaurice, 'Third Parties and the Law of Treaties',(2002) 6 Max Planck Yearbook of United Nations Law 37-I37, concluding that the principle pacta tertiis nec nocent nec prosunt remains the general rule and that rights and obligations of third states stemming from treaties to which they are not parties remain exceptional.

4I. H. Kelsen, Principles of International Law, rev. and ed. R. W. Tucker (I966), 487.

42. See Art. 63 ('Treaties providing for objective régimes') of the International Law Commission (ILC) draft for the Vienna Convention on the Law of Treaties of 1964 by special rapporteur Sir Humphrey Waldock: 'A treaty establishes an objective régime when ... the intention of the parties is to create in the general interest 
demilitarization of the Aaland Islands ${ }^{43}$ or a free passage through the Kiel Canal. ${ }^{44}$ Further examples are the League of Nations' Mandate on Namibia,45 the Antarctic Treaty ${ }^{46}$ and the Deep Sea regime. ${ }^{47}$ These contractual regimes oblige and empower third parties to the limited extent that they must tolerate the regime and may request its implementation. ${ }^{4}$

A closely related institution are world-order treaties, formerly called traités-lois. Such treaties have been adopted in the subject areas of human rights, law of the sea, environmental law, world trade law and international criminal law. A characteristic feature of these world-order treaties is their quasi-universal membership. A more contested characteristic is their arguably non-reciprocal structure, which means that they embody collective obligations serving global community interests which transcend the individual interests of the state parties. ${ }^{49}$ In the words of the International Court of Justice (ICJ) with regard to the genocide convention: 'In such a convention, the contracting states do not have any interest of their own; they merely have, one and all, a common interest. ${ }^{50}$ Even more contested is the potential of those world-order treaties to bind non-parties to the treaties' basic rules without making the third states formally a party to the treaty. Such an effect is, for example, attributed

general obligations and rights relating to a particular region, State, territory, locality, river, waterway, or to a particular area of the sea, sea-bed, or air-space ...' (Third Report on the Law of Treaties, (I964) II Yearbook of the International Law Commission 26, emphasis added). The construction of an objective regime has, however, not without grounds, been criticized as reflecting imperialist tendencies.

43. According to the International Commission of Jurists of the League of Nations, the Treaty of Paris of 30 March I856, which demilitarized the islands with effect for the state of Finland (which came into being only later), had created a 'véritable droit objectif, de vrais statuts politiques, dont les effets se font sentir en dehors même du cercle de parties contractantes' (Rapport de la Commission Internationale de Juristes Chargée par le Conseil de la Société des Nations de donner un avis consultatif sur les aspects juridiques de la Question des Iles d'Aaland, Société des Nations, J.O. Suppl. Spéc. No. 3 (October I920) 3, at 17 ).

44. Art. 380 of the Treaty of Versailles of 28 June r 9 I 9 opened the Canal to vessels of all nations ('toutes les nations

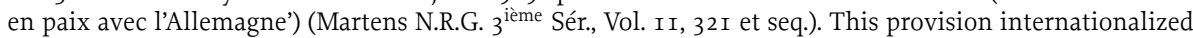
the until then purely national waterway 'for the benefit of all nations of the world' (Wimbledon, (I923), PCI) Ser. A, No. I, at 22).

45. The contractually agreed mandate was not terminated by the dissolution of the League of Nations (International Status of South West Africa, Advisory Opinion, [1950] ICJ Rep. I28, I32-6). See also Judge Sir Arnold McNair: 'From time to time it happens that a group of Great Powers, or a large number of States both great and small, assume a power to create by a multipartite treaty some new international régime or status which soon acquires a degree of acceptance and durability extending beyond the limits of the actual contracting parties, and giving it an objective existence. This power is used when some public interest is involved, and its existence often occurs in the course of a peace settlement at the end of a great war' (McNair, Separate Opinion, ibid., I46, at 153 (emphasis added)).

46. Art. X of the Antarctic Treaty of I December I959 (UNTS Vol. 7I, 402) may be interpreted as imposing on third parties an obligation to intervene (see critically B. Simma, "The Antarctic Treaty as a Treaty Providing for an "Objective Regime", (1986) Ig Cornell International Law Journal i 89-209).

47. See UNCLOS of ıo December I982, UNTS Vol. I833, 3, Art. I37. See on the third-party effect of this provision R. Wolfrum, Die Internationalisierung staatsfreier Räume (I984), at 395-6.

48. E. Klein, Statusverträge im Völkerrecht (I980), on the third-party effects at 345-8.

49. See, seminally, B. Simma, 'From Bilateralism to Community Interests', (I 994) 250-VI Recueil des cours 2 I 7-384. The emergence of community interests is one of the core propositions of the Spanish 'objectivist school' of international law; see, e.g., J. D. González Campos, L. I. Sánchez Rodríguez, and P. A. Sáenz de Santa María, Curso de derecho internacional público (2002), 68. See with regard to the human rights instruments Human Rights Committee, General Comment No. 24 (I994), paras. 8 and I7 (CCPR/C/2 I/Rev. I/Add.6). Negating the 'collective' character of the WTO-Agreement: J. Pauwelyn, 'A Typology of Multilateral Treaty Obligations: Are WTO Obligations Bilateral or Collective in Nature?' (2003) I4 EJIL 907-5I.

50. Reservations to the Convention on the Prevention and Punishment of the Crime of Genocide, [I95I] ICJ Rep., at 23 (emphasis added). 
by (so-far minority voices) to the Fish Stocks Agreement of I $995 .{ }^{5 \mathrm{I}}$ Finally, the new regimes are increasingly enforced by international courts and tribunals, such as the International Criminal Court (ICC) or the International Tribunal for the Law of the Sea (ITLOS), or on the regional level by the European Court of Human Rights (ECHR). This is noteworthy, because judicial review is one of the core elements of the rule of law.

A final manifestation of the erosion of the consent requirement is 'legislation' by the Security Council. ${ }^{22}$ After I989 the Security Council has occasionally issued 'generic resolutions', ${ }^{33}$ which may - due to their general and abstract character aptly be qualified as 'laws'. These laws are binding via Article 25 of the UN Charter and circumvent eventual ratification requirements of parallel treaties. Overall, the renouncement of consent means to recast sovereignty by transforming it into the right and power to participate in, but not to veto, international decision-making. From this perspective, constitutionalism supplants voluntarism.

\subsection{Global community interests}

Core provisions of the world-order treaties, as already mentioned, but also some customary law principles have been called 'public interest norms'. ${ }^{54}$ In fact, the emergence of these norms is sometimes, notably in continental scholarship, considered to be the main element of global constitutionalism: 'Constitutionalization of public international law means recognition of interests of the community of states and the introduction of mechanisms for their implementation. 55 These global common interests relate to global goods and/or reflect common assumptions and shared attitudes. At least in part, the relevant norms embody universal values. Examples of global community interests are the interest in protecting human beings and the common heritage of mankind, or in realizing sustainable development globally. More contested is the interest in realizing global free trade.

\subsection{Statehood and recognition}

We witness changes in the concept of statehood and a legal evolution regarding the recognition of states and governments. ${ }^{56}$ In this context, the principle of

5I. See notably the Fish Stocks Agreement, Art. 33(2): 'States Parties shall take measures consistent with this Agreement and international law to deter the activities of vessels flying the flag of non-parties which undermine the effective implementation of this Agreement' (Agreement for the Implementation of the Provisions of the United Nations Convention on the Law of the Sea of I o December I 982 Relating to the Conservation and Management of Straddling Stocks and Highly Migratory Fish Stocks of 8 September I 995, (I995) 34 ILM I 542 et seq., emphasis added). See on the third-party effect J. Ziemer, Das gemeinsame Interesse an einer Regelung der Hochseefischerei (2000), I 87 et seq.

52. See S. Talmon, 'The Security Council as World Legislature', (2005) 99 AJIL I75-93.

53. Notably UN Doc. S/RES/827 (I993), installing the ICTY; UN Doc. S/RES/I373 (200I) on the financing of terrorism; UN Doc. S/RES/I 540 (2004) on weapons of mass destruction in the hand of private actors.

54. J. Delbrück (ed.), New Trends in International Lawmaking - International 'Legislation' in the Public Interest (I997).

55. J. A. Frowein, 'Konstitutionalisierung des Völkerrechts', (2000) 39 Berichte der Deutschen Gesellschaft für Völkerrecht 427, at 447.

56. Under the declarative theory of recognition, the act of granting or withholding recognition does not in theory affect statehood (the international legal personality). However, the idea of an 'objective' legal personality of a 
effectiveness is marginalized, and standards of legitimacy (concerning human rights and democracy) are set up. ${ }^{57}$ For instance, the UN organs declared as 'null and void' the South African Constitution of 1984 which entrenched the apartheid system, because it was contrary to the principles of the UN Charter..$^{8}$

After the break-up of the Soviet Union and Yugoslavia, the European Community (EC) set up guidelines for the recognition of new states in Eastern Europe and the former Soviet Union in which the new states were required - inter alia - to subscribe to the commitments 'in the Final Act of Helsinki and the Charter of Paris, especially with regard to the rule of law, democracy and human rights'.59 The EC then installed an Arbitral Commission which determined by means of a quasi-judicial examination whether the requirements for recognition were satisfied.

Another example is the treatment of the Taliban government in Afghanistan. In I996, the Taliban sought international recognition and a representation at the United Nations. However, the new government was recognized only by Pakistan, Saudi Arabia, and the United Arab Emirates, and was not allowed to send its representative to the United Nations. Refusal of recognition was explained by reference to the Taliban government's violations of human rights, notably of women's rights. ${ }^{60}$

East Timor's process towards independence was closely monitored by the UN. The new state's constitution of 22 March 2002 was signed in the presence of the Secretary-General's Special Representative and Transitional Administrator, and the relevant UN reports emphasized that the Constitution provided 'for a unitary democratic state, based on the rule of law and the principle of the separation of powers' ${ }^{61}$

Finally, after the Iraq war, a Security Council Resolution formulated, albeit implicitly, conditions for the recognition of a new Iraqi government. The Council here encouraged the people of Iraq to form 'a representative government based on the rule of law that affords equal rights and justice to all Iraqi citizens without regard to ethnicity, religion, or gender'. ${ }^{62}$

Although democratic legitimism in international recognition had been practised earlier, notably by the United States and the United Kingdom in the nineteenth century and at the beginning of the twentieth century, this practice was - before

state based on 'objective' facts even in the absence of any recognition is somewhat artificial. The artificiality of the construction was highlighted by the post-I 989 recognition practice which pro-actively consolidated weak political entities which did not fulfil or only to a limited degree fulfilled the ordinary criteria of statehood.

57. Most recently J. d'Aspremont, 'La création internationale d'Etats démocratiques',(2005) Iog Revue Générale de Droit International Public 889, concluding that 'nowadays, international administrations of territories entail the creation of democratic institutions.... it is beyond doubt that whilst the international community cannot entirely control the birth of States, it strives to ... impose a precise type of political regime' (quotation from English abstract). See also B. A. Roth, Governmental Illegitimacy in International Law (I 999); R. Rich, 'Recognition of States: The Collapse of Yugoslavia and the Soviet Union', (I993) 4 EJIL 36-65; Frowein, supra note 55, at 429-32; J. Crawford, The Creation of States in International Law (2006).

58. UN Doc. S/RES/554 (I 984 ), paras. I-2 and UN Doc. A/39/2 (I984), para. I.

59. Guidelines of I6 December I991, repr. in (I992) 3I ILM I 486 et seq.

6o. See in the press, e.g., M. Spillmann, 'Kein Ende des Blutvergiessens in Afghanistan', Neue Züricher Zeitung, 27 Aug. I999.

6I. Report of the Secretary-General on the United Nations Transitional Administration in East Timor of 17 April 2002, para. 5 (UN Doc. S/2002/432); see also UN Doc./S/RES/I480 (2003), para. 2 of the Preamble.

62. UN Doc. S/RES/I483 (2003). 
I 989 - too selective to become customary law. After I 989 the density of precedents may work towards the emergence of a legal principle embracing substantial conditions for international recognition beyond the effectiveness test.

\subsection{The intertwinement and complementarity of international (constitutional) law and national (constitutional) law}

The emergence of an additional, more 'individualist' basis for the legitimacy of international law implies that international law does care about domestic constitutional standards. States are no longer a black box for international law, because international organizations, treaty bodies, foreign states, officials of foreign state organs, and transnational non-governmental organizations (NGOs) scrutinize and assess national constitutional systems, and impose material standards of governance relating, inter alia, to the protection of human rights and democracy. This also means that both spheres (the international and the national) can no longer be neatly separated. They already complement each other and should do so even more in the future.

Dense international legal obligations require states to enact specific domestic legislation, even on the level of constitutional law. For instance, the Swiss constitution (Bundesverfassung, BV) of I8 April 1999 incorporates in Article 25(2) the non-refoulement principle, and seeks to fulfil the duty to protect children imposed on member states by the Convention on the Rights of the Child (Art. 2(3)) by introducing a novel constitutional article on the protection of children. ${ }^{6} 3$ However, the thicker the web of international legal obligations becomes, the more resistance meets the classical claim of supremacy of all international law over all domestic law. States rather insist upon at least safeguarding core constitutional principles against international encroachment. In this situation the relationship between international and national law cannot plausibly be described as a clear hierarchy. Both bodies of norms rather form a network. ${ }^{64}$

One exemplary field of intertwinement of international and national constitutional principles is the field of democratic law and governance. ${ }^{65}$ The globalization of economic, political, military, and legal problems, relationships, and power structures has led to three democratic deficiencies within nation states. A first deficiency stems from the fact that - because of global interdependencies - state activities have become further reaching and more extraterritorial. This means that political decisions (e.g. on tax reduction, raising environmental standards, building nuclear plants) affect people in other states, people who have not elected the decision-makers and can in no way control them. A second aspect is that the transnational character of issues, and the mobility and interaction of individuals, firms, and NGOs (despite the increasing extraterritorial effects of regulation), have on the whole reduced

\footnotetext{
63. Art. I I BV.

64. See also infra, section 6.5 .

65. See for the international imposition of standards of democracy to states infra section 6.4. See on the effects of globalization on domestic democracy A. von Bogdandy, 'Demokratie, Globalisierung, Zukunft des Völkerrechts - eine Bestandsaufnahme', (2003) 63 Zeitschrift für ausländisches öffentliches Recht und Völkerrecht $853-77$.
} 
the power of the nation state to tackle and solve problems by itself. In terms of democracy, this general loss of effectiveness reduces in turn the effectiveness of self-determination, or democratic output. So here we face a kind of indirect decline of democracy. ${ }^{66}$ The third deficiency lies in the lack of any democratic mandate for or control of non-state decision-makers. In order to regain control, states have to co-operate within international organizations, through bilateral and multilateral treaties and so forth. But these conventional methods of global governance aggravate the democratic deficit, because the link between voters and decision-makers is loosened. Non-state law making is in all international institutions law making by representatives of the states' executive branches, not by parliaments. Moreover, the complexity of the process blurs the lines of responsibility between the actors in international regimes, and further threatens the functioning of the institutions of control and call-back. The conclusion to draw from all this is that if we want to preserve a minimum level of democratic governance, then we have to move beyond the state and establish compensatory, transnational democratic structures. ${ }^{67}$

\subsection{Global public-private constitutionalism}

A final phenomenon which can be analysed from a constitutional perspective is the growing participation of non-state actors, such as NGOs, transnational corporations, and individuals in international law making and law enforcement. Public opinion and the involvement of actors from civil society and the private sector have been acknowledged by the United Nations itself to be key factors of effective action on global priorities. ${ }^{68}$

In recent years NGO lobbying has strongly influenced international standardsetting. Notably, the Landmines Convention of $1997^{69}$ and the ICC Statute of 1998 would probably not have come into being without the intense work of transnational NGO coalitions. Conversely, NGO resistance was a crucial contribution to the failure of the projected Multilateral Agreement on Investment (MAI) in I998. On the implementation level, it is well known that the efficiency of human rights monitoring to a large extent depends on shadow reports of NGOs submitted to the respective treaty bodies. ${ }^{70}$ World Trade Organization (WTO) law is also increasingly enforced by ad hoc public-private trade litigation partnerships formed by private firms in collaboration with governments. ${ }^{7 \mathrm{I}}$ Moreover, international environmental

66. M. J. Sandel, Democracy's Discontent: America in Search of a Public Policy (I996), 202.

67. 'Democracy within a nation-state requires democracy within a network of intersecting international forces and relations. This is the meaning of democratization today.' D. Held, 'Democracy, the Nation-State and the Global System', in D. Held, Political Theory Today (I991), I97, at 232. See for concrete proposals We the Peoples: Civil Society, the United Nations and Global Governance: Report of the Panel of Eminent Persons on United Nations - Civil Society Relations (June 2004), Doc. A/58/8I7 (Cardoso Report), available at http://www.unngls.org/UNreform.htm (last visited I Sept. 2005), Part VI, 'Engaging with elected representatives' (paras. IOI-52).

68. Cardoso Report, supra note 67.

69. Convention on the Prohibition of the Use, Stockpiling, Production and Transfer of Anti-personnel Mines and on Their Destruction of I 8 September I997, UNTS Vol. 2056, at 2 I I.

70. See also ICC Statute, supra note 28 , Arts. I5(2) and 44(4), on information submitted by NGOs and on 'gratis personnel' employed by the ICC.

7 I. G. Shaffer, Defending Interests: Public-Private Partnerships in WTO Litigation (2003). 
law is implemented by public-private partnerships for sustainable development, ${ }^{72}$ for instance the Prototype Carbon Fund (PCF) within the Clean Development Mechanism of the Kyoto Protocol. ${ }^{73}$ Finally, the compliance mechanism of the Aarhus Convention on Environmental Information ${ }^{74}$ can be triggered by private persons. ${ }^{75}$

This trend erodes the public-private split on the international plane. ${ }^{76}$ It may on the one hand - contribute to constitutionalization, because it integrates the transnational civil society into the fabric of international law and thereby arguably promotes the constitutional principles of broad deliberation, transparency, and public accountability. However, opening up the circle of law makers and law enforcers creates new problems of legitimacy of international law. The multiple actors which contribute to the generation of hard and (more often) soft transnational norms are not per se legitimate law makers, and their empowerment may camouflage the tendency of governments to avoid commitment to hard and binding law. Nevertheless, these new structures have been termed 'global civil constitutions'. ${ }^{77}$

\section{Micro-COnStitutionalization in InTERnAtional ORGANIZATIONS}

\section{I. General}

Set somewhat apart from the general debate on constitutionalism, one distinct subject area has been particularly scrutinized through a constitutionalist prism, namely the law of international organizations. Various theories have for a long time qualified the foundational treaties of international organizations as the constitution

72. These partnerships were officially recognized as 'Type II outcomes' at the 2002 World Summit on Sustainable Development. See Plan of Implementation, revised version of 23 Sept. 2002 (Doc. A/CONF.I 99/20), available at http://www.johannesburgsummit.org/html/documents/summit_docs/2309_planfinal.htm(visited I June 2004). In scholarship, C. Streck, 'The World Summit on Sustainable Development: Partnerships as New Tools in Environmental Governance', (2002) I3 Yearbook of Environmental Law 3-95.

73. See the World Bank Executive Directors' decision of 20 July 1999 to establish the PCF, available at http://carbonfinance.org/pcf/router.cfm?Page=About (visited 27 May 2004). The World Bank's partnership with the public and private sectors is intended to mobilize new resources for its borrowing member countries while addressing global environmental problems through market-based mechanisms. The PCF will invest contributions made by companies and governments in projects designed to produce emission reductions consistent with the Kyoto Protocol. Participants in the PCF will receive a pro rata share of the emission reductions.

74. Convention on Access to Information, Public Participation in Decision-making and Access to Justice in Environmental Matters of 25 June I998, available at http://www.unece.org./env/pp/documents/cep43g.pdf (last visited 27 May 2004).

75. Decision $\mathrm{I} / 7$ on review of compliance, part. VI 'Communications from the Public', paras. I 8-24, available at www.unece.org/env/pp/compliance.htm (last visited 27 May 2004).

76. Note that the term 'public-private split' in domestic law is often used to designate the separation of two distinct branches of law, namely public and private law. Both branches of law are state-made law to a large extent. A different question is whether private entities are (by the relevant legal framework) authorized to make law. The traditional and uncontested forms of law created by private actors are contracts which bind the (private) parties. The novel phenomenon (both on the national and on the international plane) is to entrust private actors with standard-setting. Private actors are thereby allowed to make (or to participate in the making of general rules which potentially bind third actors. This is meant by 'erosion of the public-private split' in this paper.

77. G. Teubner, 'Globale Zivilverfassungen: Alternativen zur staatszentrierten Verfassungstheorie’, (I993) 63 Zeitschrift für ausländisches öffentliches Recht und Völkerrecht I-28. 
of that respective organization. French institutionalist thinking led to the conclusion that

Sous ce profil, l'acte institutif d'une Organisation déterminée est bien un traité international, fondé, en tant que tel, sur la volonté des contractants et donc soumis, au moment de sa formation, à leur volonté, mais il est par ailleurs destiné à devenir la constitution, c'est-à-dire l'acte de fondation de l'Organisation, auquel celle-ci se rattache tout au long de son existence. On pourrait dire, par conséquent, que l'acte institutif revêt la forme du pacte, mais possède la substance de la constitution: né sur la base d'une convention, il dépasse, avec le temps, son origine formelle, jusqu'à devenir une constitution de durée indéterminée dont le développement déborde le cadre à l'intérieur duquel elle avait été initialement conçue. ${ }^{78}$

The ICJ found that

From a formal standpoint, the constituent instruments of International Organizations are multilateral treaties.... Such treaties can raise specific problems of interpretation owing, inter alia, to their character which is conventional and at the same time institutional. ${ }^{79}$

We may call this analysis a 'micro-constitutional analysis'. ${ }^{80}$ In this particular context, constitutionalism is a competing paradigm to functionalism. Functionalist integration strategies have concentrated on forms of (ostensibly) apolitical and technical international co-operation in order to reach the objective of (ultimately political) integration more readily. Notably, David Mitrany had already during the Second World War advocated an international integration strategy 'which would rather overlay political divisions with a spreading web of international activities and agencies, in which and through which the interests and life of all nations would be gradually integrated'. '[E]conomic unification would build up the foundations for political agreement, even if it did not make it superfluous. In any case, as things are the political way is too ambitious. ${ }^{8 I}$

On a different level again, a constitutionalist set of arguments in the law of international organizations may take over the role of functionalism: as constitutionalism is all about limited government, it might provide a novel justification for legal constraints on the increasing and hence potentially intrusive or even abusive activities of those organizations. This expectation is not shared by Jan Klabbers, who has pointed out that the constitutional arguments will in this regard probably be as powerless as their precursor, the doctrine of functional necessity. Calls for micro-constitutionalism in international organizations are, so the critique goes, too single-mindedly focused on organizations as separate entities, in isolation from their member states. Moreover, constitutional limitations can always be overcome by agreement of precisely those subjects which they are supposed to control. Finally,

78. R. Monaco, 'Le caractère constitutionnel des actes institutifs d'organisations internationales', in Mélanges offerts à Charles Rousseau (I974) I53, at I 54.

79. Legality of the Use by a State of Nuclear Weapons in Armed Conflict, Advisory Opinion, [I 996] ICJ Rep. 66, para. I9.

80. P.-M. Dupuy, 'L'unité de l'ordre juridique international', (2002) 297 Recueil des cours I 5, at 227.

81. D. Mitrany, A Working Peace System (1944), 6 and 54, and Mitrany, The Progress of International Government (I933). 
constitutional techniques are not able to meet the challenge of fragmentation. ${ }^{82}$ This is not the place to discuss these three objections in detail. ${ }^{83}$ Suffice it to point out that the idea of constitutionalism includes awareness that the independent international legal personality of international organizations is only the legal side of a complex situation in which the member states play a dual role as parts of the organization's organs and as international legal subjects outside the organization. State constitutions relate as well to the legal and the power aspects of states and can do no more than design 'auxiliary precautions', as James Madison has put it, ${ }^{84}$ to enable those in power to control themselves.

\subsection{Constitutionalization of the EU and the WTO as spearheads}

A particular case of constitutionalization of an international organization is the example of the European Community/European Union. Many observers argue that the EC/EU possesses a constitution in a material sense, independently of the nonratification of the Constitutional Treaty of 2004. ${ }^{85}$ However, the EC/EU is special, notably because the EC has pronounced supranational features. ${ }^{86}$ Also, the EC/EU is a regional entity which can build on a comparatively strong political and cultural consensus and shared practices. Because of its unique characteristics, the constitutionalization of the EC/EU is hardly suitable as a model for world-wide constitutionalism. However, specific parts of the European debate, notably the discussion on the democratic deficiency of European governance, may give impulses for the analysis of democratic governance on a global scale.

In contrast, the WTO appears to pioneer not only the micro-constitutionalist analysis but even the macro-constitutional analysis of the entire international order as such. However, in the field there is still less agreement than with regard to the EC/EU about the legal aspects which might constitutionalize the WTO. The meanings and connotations ascribed to the concepts of 'constitution' and 'constitutionalization' vary more than in the context of EU law, according to the authors' scholarly discipline, their national background, and probably also their (trade-)political ideology. ${ }^{87}$

\footnotetext{
82. J. Klabbers, 'Constitutionalism Lite', (2004) I International Organizations Law Review 31, at 44-5.

83. See on the problem of fragmentation infra, section 7.I.

84. Supra note I7.

85. See on the EU constitution J. Gerkrath, L'emergence d'un droit constitutionnel pour l'Europe (I997); W. Hertel, Supranationalität als Verfassungsprinzip (I999); J. H. Weiler, The Constitution of Europe: 'Do the New Clothes Have an Emperor?', and Other Essays on European Integration (I999); C. Dorau, Die Verfassungsfrage der Europäischen Union: Möglichkeiten und Grenzen der europäischen Verfassungsentwicklung nach Nizza (200I); Peters, supra note 6; T. Schmitz, Integration in der supranationalen Union (200I); P. Häberle, Europäische Verfassungslehre (2006); A. Verhoeven, The EU in Search of a Democratic and Constitutional Theory (2002); T. Giegerich, Europäische Verfassung und deutsche Verfassung im transnationalen Konstitutionalisierungsprozess: Wechselseitige Rezeption, konstitutionelle Entwicklung und föderale Verflechtung (2003); A. von Bogdandy and J. Bast, Principles of European Constitutional Law (2005); A. López Pina, Europa, un proyecto irrenunciable: La Constitución para Europa desde la teoría constitucional (2004); P. Cruz Villalón, La Constitución inédita: Estudios ante la constitucionalización de Europa (2004); C. Philip, La constitution européenne (2004).
}

86. Supranationality is here understood as resulting from the wealth of the organization's competencies, compulsory adjudication, its law making powers without need for transformation by member states, and the direct effect of many provisions of EC law.

87. See apart from the literature in the following footnotes the numerous works of E.-U. Petersmann, beginning with Petersmann, Constitutional Functions and Constitutional Problems of International Economic Law (I99I); most recently Petersmann, 'Human Rights, Constitutionalism, and the WTO: Challenges for WTO 
Those diverse perspectives have recently been categorized as 'rights-based', 'institutional', or 'metaphysical' approaches to WTO constitutionalization. ${ }^{88}$

A first aspect discussed under the heading of 'constitutionalization' is the legalization of dispute settlement, that is, the creation of a scheme of quasi-arbitration by panels and the Appellate Body that replaces the former diplomatic means of settlement. In this context, judicial norm generation by the Appellate Body has been called the core element of WTO constitutionalization. It has been argued 'that the case-law of the WTO is beginning to display some characteristics ordinarily associated with constitutional case law', because it exhibits an explicit concern with the delineation of powers, borrows constitutional doctrines and techniques, such as proportionality, and has extended its scope into subject matters which were previously considered to pertain to the domestic constitutional domain. ${ }^{89}$ Also, growing consideration by the dispute settlement organs of non-trade issues such as human rights and environmental protection has been praised as a genuinely constitutional approach, because here the technique of balancing of interests is applied. ${ }^{90}$

Second, the traditional trade law principles of most-favoured nation and national treatment are increasingly viewed as two facets of a constitutional principle of non-discrimination ultimately benefiting the ordinary citizens (importers, exporters, producers, consumers, tax-payers). This view gives rise to the quest for a general maxim of interpretation of the General Agreement on Tariffs and Trade (GATT) obligations of WTO member states (and the relevant exception clauses) in the light of human rights guarantees.

A third ostensible factor of constitutionalization of WTO law is seen in one of its core functions: international trade rules neutralize the domestic power of protectionist interests. They thereby overcome the domestic political process deficiencies. ${ }^{91}$ This is a typically constitutional function, which is in the domestic realm served by fundamental rights guarantees and by judicial protection by constitutional courts. ${ }^{92}$ On the institutional level, reflection on the preconditions for majority voting in the WTO requires a constitutional analysis. ${ }^{93}$

Jurisprudence and Civil Society',(2006) I 9 LJIL 633-67. See for other approaches H. Schloeman and S. Ohlhoff, "Constitutionalization" and Dispute Settlement in the WTO: National Security as an Issue of Competence', (I999) 93 AJIL 424-5I; J. McGinnis and M. Movsesian, 'The World Trade Constitution', (2000) I I 4 Harvard Law Review 5I I-605; M. Krajewski, 'Democratic Legitimacy and Constitutional Perspectives of WTO Law', (200I) 35 Journal of World Trade Law I67-86; A. von Bogdandy, 'Verfassungsrechtliche Dimensionen der Welthandelsordnung', (200I) 34 Kritische Justiz 264-8I; M. Hilf and W. Benedek, 'Konstitutionalisierung der Welthandelsordnung', in (200I) 27 Berichte der Deutschen Gesellschaft für Völkerrecht 257-330 (Eng. summaries at 28rand 326); S. Charnovitz, 'WTO Cosmopolitics', (2002) 34 New York University Journal of International Law and Politics 299-354; D. C. Esty, 'The World Trade Organization's Legitimacy Crisis',(2002) I World Trade Review 7-22; P. Gerhart, 'The Two Constitutional Visions of the World Trade Organization', (2003) 24 University of Pennsylvania Journal of International Economic Law r; T. Cottier, 'Konstitutionalisierungsprobleme im internationalen Wirtschaftsrecht: Verfassungsrechtliche Herausforderungen im Rahmen der WTO', in W. Kälin and T. Cottier (eds.), Die Öffnung des Verfassungsrechts: Symposium zum 65. Geburtstag von Prof.Jörg Paul Müller, (2005) recht Sonderheft 50-62. See also the contributions to the 'Mini-Symposium' in (2004) 7 JIEL, at 585 et seq.

88. D. Z. Cass, Constitutionalization of the World Trade Organization: Legitimacy, Democracy and Community in the International Trading System (2005).

89. D. Z. Cass, "The "Constitutionalization" of International Trade Law: Judicial Norm-Generation as the Engine of Constitutional Development in International Trade', (200I) I 2 EJIL 39, at 42.

90. Cottier, supra note 87 , at 56-7.

91. Petersmann, Constitutional Functions, supra note 87, Ch. V (at 96 et seq.).

92. J. Hart Ely, Democracy and Distrust (I980).

93. Cottier, supra note 87 , at 57. 
Finally, and probably most importantly, the option of directly applying GATT rules (which is currently still rejected by most courts) can be analysed in a constitutional perspective. The capability of self-interested trade participants to enforce international trade rules before domestic courts would empower the individuals and would enable the judiciary to check the executives which otherwise enjoy unfettered discretion in applying the rules which were actually designed to restrain those very actors. This is the classic theme of constitutionalism, which seeks to contain political power in order to safeguard the autonomy of the individual.

\section{LINKING THE NATIONAL AND THE INTERNATIONAL DISCOURSES ON CONSTITUTIONS}

The remaining task is to link the national lawyer's understanding of constitutions and constitutionalism (as sketched out in section 3) with the international lawyers' discourse on international constitutionalization (as explained in sections 4 and 5).

\section{I. Diagnosis: disjunction of the discourses}

The first and important finding is that the national and international discourses on constitutions and constitutionalism are basically unconnected. ${ }^{94}$ Constitutionalization and constitutionalism in the international sphere so far seem to mean something quite different from constitutionalism within states. Obviously some implicit translation from the national to the international sphere has been performed, but the terms of that translation are not clear. Moreover, many phenomena which are discussed by international lawyers under the heading of constitutionalization may simply be called thicker legalization and institutionalization, without any need to resort to the notion of constitution.

Moreover, the overall tendencies in international law could also be characterized as an evolution from a civil-law-like system ('horizontal' relations between juxtaposed, autonomous actors) to a more public-law-like system (strengthened central authority, hierarchical elements, bindingness without or against the actors' will). This analysis does not altogether differ from the constitutionalist reading, because the move from civil law to public law is mostly associated with the shift from contract to constitution.

In order to connect the disjointed discourses, we might try to apply the constitutional scheme to international law in a stricter mode than usual.

\subsection{Constitutional form?}

As far as the first formal property of constitutional law is concerned, namely that it is written, Bardo Fassbender and others have argued that the UN Charter is the constitutional document of international law. 95 The main justification for this

\footnotetext{
94. The quest for compensatory constitutionalism as formulated here of course includes the suggestion of linking those two academic discourses.

95. B. Fassbender, UN Security Council Reform and the Right of Veto: A Constitutional Perspective (I998); Fassbender, supra note I8, at 529-6I9; R. Macdonald, 'The Charter of the United Nations in Constitutional Perspective',
} 
construction is that the United Nations is the primary institutional representative of the international community, with quasi-universal membership. The United Nations is therefore the (only) institution which furnishes the international community with organs. ${ }^{96}$

This conception has the advantage of being clear. On the other hand, the UN Charter does not codify enough of what is fundamental for the functioning of the international legal order. Rules of arguably constitutional importance are for instance enshrined in the Vienna Convention on the Law of Treaties (VCLT), or in the Human Rights Covenants or the Genocide Convention. To qualify those texts as 'constitutional by-laws' or as 'incorporated' into the Charter ${ }^{97}$ seems artificial. To conclude, there is a lot of constitutional substance outside the UN Charter. This means that a comprehensive constitutional document for the international community is lacking.

The formal feature of supremacy is present on the international plane: jus cogens is a specific, superior body of norms. It trumps conflicting international treaties ${ }^{98}$ and customary law. ${ }^{99}$ Jus cogens has therefore been qualified as 'constitutional law in a formal sense'. ${ }^{\text {roo }}$

The UN Charter itself constitutes a different, merely treaty-related, type of higher law. According to Article I03 of the UN Charter, its provisions (and arguably secondary acts such as Security Council decisions) prevail in the event of a conflict between the Charter obligations of member states and obligations under any other agreement. But UN acts privileged by Article 103 of the UN Charter still rank below jus cogens and would have to give way in case of conflict. ${ }^{\text {IoI }}$ Consequently a hierarchy of norms within international law exists. However, only a small subset, and not all international constitutional law, enjoys that precedence over ordinary international law. From a constitutionalist perspective this internal hierarchy is at least as important as the external hierarchy, that is, the supremacy of all international law in relation to domestic law. The explanation is that the supremacy of the entire body of international law (including its highly technical provisions) over all domestic law is not a constitution-like supremacy, but rather has a federal-law-like rationale (the preservation of legal unity in matters regulated on the higher level). ${ }^{\text {I02 }}$

(I 999) 20 The Australian Yearbook of International Law 205-3I; P.-M. Dupuy, 'The Constitutional Dimension of the Charter of the United Nations Revisited', (I997) I Max Planck Yearbook of United Nations Law I-33. Pioneering W. Jenks, 'Some Constitutional Problems of International Organization', (I945) 2 BYIL I I-72; A. Ross, Constitution of the United Nations: Analysis of Structure and Functions (1950).

96. Fassbender, supra note 18 , at $567-8$.

97. Ibid., at 585 and 588 .

98. Vienna Convention on the Law of Treaties (VCLT), Art. 53.

99. ICTY, Case No. IT-95-I7/I-T, Prosecutor v. Furundžija, (I999) 38 ILM 3I 7, para. I53; ECHR, Al-Adsani v. United Kingdom, Judgment of 2I November 200I, (2002) 23 HRLJ 39, para. 3, (Rozakis et al., Separate Opinion).

Ioo. A. Fischer-Lescano, 'Die Emergenz der Globalverfassung',(2003) 63 Zeitschrift für ausländisches öffentliches Recht und Völkerrecht 7 7 , at 743-8.

Ior. Application of the Convention on the Prevention and Punishment of the Crime of Genocide, [I993] ICJ Rep. 4, at 440, para. Ioo (Lauterpacht, Separate Opinion).

I02. It is therefore less important that the ICTY went beyond the intention of the authors of the VCLT and held that jus cogens also bars states from enacting countervailing national law (Furundžija, supra note 99, para. I55). 
With regard to the formal act of constitution-making by a pouvoir constituant in a revolutionary act, we can identify - on the international plane - several 'constitutional moments' ${ }^{103}$ (such as I945 or 1989). But on the whole, constitutional development on the international plane seems to occur rather gradually. This corresponds to the concept of 'constitution by evolution' as favoured in some quarters of constitutional theory. ${ }^{\mathrm{IO}}$

Overall, it seems difficult to speak of an international constitution in a formal sense, because a complete constitutional charter is missing, no formal act of constitution-making can be discerned, and the normative hierarchy is only rudimentary.

\subsection{Constitutional functions?}

As for the constitutional functions, it seems fair to say that certain international rules and principles fulfil those functions explained in section 3.2: $:^{\text {105 }}$ the creative/constitutive function is fulfilled by the norms defining the subjects of international law, such as the legal concepts of the state or of an international organization. The organizational function is performed by the meta-rules on the sources of international law, including those on treaty making or on the formation of customary law. An example of the confining function is given by international human rights law, which places important restraints on the exercise of governmental power over a state's own nationals. Political and moral guidelines are offered by aspirational texts such as the Human Rights Declaration or the Friendly Relations Declaration. The function of (socio-psychological and/or institutional) integration is performed by norms of a high symbolic value, such as the UN Charter.

However, the functional account provokes the question of how to distinguish the constitutional laws of the international community from ordinary international law, because ordinary law also performs some of those functions. Since a unified constitutional charter is missing and because a normative hierarchy within the international legal order is present-if at all-only in relation to the small subset of jus cogens, the option of establishing a clear distinction based on formal characteristics is foreclosed. It remains possible to distinguish according to the substance of the norms in question. Only those norms which have 'something fundamental' to them may be duly qualified as constitutional norms, as has been formulated with regard to the British Constitution. ${ }^{\mathrm{I} 6}$ But this distinction is inevitably blurry and contestable.

\subsection{Constitutional values?}

It is possible, but by no means compelling, to find a constitution in the third, narrowest, value-loaded sense on the international plane. ${ }^{\text {I07 }}$

\footnotetext{
I03. To borrow a term from B. Ackerman, We The People, Vol. I: Foundations (I 991).

I04. Supra notes 25 and 26.

I05. See already G. Scelle, 'Le droit constitutionnel international', (I933) Mélanges Raymond Carréde Malberg 50I, at 5I4; R. Uerpmann, 'Internationales Verfassungsrecht', (200I) 56 Juristen-Zeitung 565, at 567-9.

I06. C. Turpin, British Government and the Constitution: Text, Cases and Materials (2002), 5.

I07. See sceptically W. Kälin, 'Der Menschenrechtsschutz der UNO: Ein Beispiel für die Konstitutionalisierung des Völkerrechts?', in W. Kälin and T. Cottier (eds.), Die Öffnung des Verfassungsrechts: Symposium zum
} 
The ideal of democracy is being propagated in international law. One justification for the concern of international law in the democratization of states is the democratic peace thesis, as formulated by Immanuel Kant in Perpetual Peace(I 795), which points to the fact that 'liberal democracies' do not wage war against each other. ${ }^{\text {I08 }}$ (However, the most powerful 'liberal democracy' very often does wage war against various other types of regime.) In any case, numerous international legal provisions (both universal and regional in scope) and important soft-law documents grant individuals the right to participate in the conduct of public affairs and the right to vote in elections, ${ }^{\text {I09 }}$ or generally call on states to establish democratic governments. ${ }^{\text {Io }}$ But despite these prescriptions with universal ambit, and despite the obvious spread of liberal multi-party democracies after the collapse of the socialist bloc after I989, many states of the world, notably in the Arab and Asian regions, are not governed democratically. ${ }^{\text {II }}$

Second, the international institutions themselves hardly satisfy the requirements of democracy and of the separation of powers (or reasonably modified versions of these basic ideas). For instance, the UN Security Council, due to its composition and the power of veto which merely consecrates the power constellation in being after the Second World War, is not a body which in a meaningful way represents the international community. In other international organizations as well, decision-making is often lacking in transparency, the 'parliaments' of those organizations do not possess hard powers, and the decision-makers are not accountable to state parliaments

65. Geburtstag von Prof. Jörg Paul Müller, (2005) recht Sonderheft 42, at 45. But see C. Tomuschat, 'Die internationale Gemeinschaft', (I995) 33 Archiv des Völkerrechts I, at 7: There is a constitution of the international community in which certain basics of peace and justice are laid down. See also E. de Wet, "The Emergence of International and Regional Value Systems as a Manifestation of the Emerging International Constitutional Order', (2006) I9 LJIL 6I I-32. See for a powerful analysis of the 'relativity of the universal' and the 'universality of the relative' in the current international legal order, and a call for 'ordered pluralism', M. Delmas Marty, Le relative et l'universel (2004).

I08. See for the claim that liberal principles and institutions make a difference to the conduct of the foreign affairs of states M. W. Doyle, 'Kant, Liberal Legacies, and Foreign Affairs', (I983) I 2 Philosophy and Public Affairs 205. See for empirical evidence B. Russett, J. Oneal, and D. Davis, 'The Third Leg of the Kantian Tripod for Peace: International Organizations and Militarized Disputes, I950-I985', (I998) 52 International Organization 44I67. The authors 'find major benefits of joint democracy ... If both members of a dyad are fully democratic, conflict is 35 percent less likely'.

I09. Universal Declaration of Human Rights, Art. 21; CCPR, Art. 25; ACHR, Art. 23(I); Banjul Charter, Art. I3(I).

I Io. See OAS Charter (last amended on Io June 1993), Arts. 2(b), 9; Statute of the Council of Europe of 5 May 1949, Preamble; NATO Treaty of 4 April I949, Preamble; CSCE Charter of Paris for a New Europe of 2I November 1993; Implementation of the United Nations Millennium Declaration, UN Doc. A/57/270 of 3I July 2002, Part V: 'Human rights, democracy and good governance', paras. 82 et seq.; UN Commission on Human Rights, Res. I999/57 of 27 April I999, 'Promotion of the right to democracy'; OAS Interamerican Democratic Charter of I I September 200I (text in (200I) 4I ILM I289); Resolution of the UN General Assembly on the 2005 World Summit Outcome of 24 October 2005 (UN Doc. A/RES/60/I), para. I35: 'We reaffirm that democracy is a universal value ... I36. We renew our commitment to support democracy by strengthening countries' capacity to implement the principles and practices of democracy .... See in scholarship G. Fox and B. Roth (eds.), Democratic Governance and International Law (2000); S. Wheatley, 'Democracy in International Law: A European Perspective', (2002) 5I ICLQ 225-47; L. Ali Khan, A Theory of Universal Democracy: Beyond the End of History (2003); J. I. Ibegbu, Right to Democracy in International Law (2003).

I I I. Although not always to be taken at face value, the surveys of 'Freedom House' are helpful to assess the degree of democracy in countries around the world. See www.freedomhouse.org/research/survey2005.html (last visited I Sept. 2005). 
or to citizens. ${ }^{\text {II2 }}$ However, both the United Nations and the WTO are currently engaged in serious efforts at some 'democratization' by improving transparency and engaging national parliaments. ${ }^{\mathrm{II} 3}$

An international rule of law would probably require some form of judicial review (or other types of control of legality) of acts of states and other subjects of international law. This is currently guaranteed only selectively.

In contrast, the endorsement of human rights comes closest to universal acceptance. About three quarters of the states (more than I 40, of a total of I 92 states) have ratified the two universal Human Rights Covenants, and membership is steadily and markedly increasing. However, there are important divergences in the interpretation of the internationally enshrined human rights, and great deficiencies in implementation.

All in all, the three traditional value-driven organizing principles of constitutional government (democracy, human rights, and rule of law) are only tentatively and selectively applied as international law prescriptions directed at states, and are only spasmodically realized within international institutions. However, we have seen that the emergence of public interest norms is considered to be a core element of international constitutionalization. We might therefore call these norms 'constitutional norms'. As already pointed out, these norms refer, for example, to the protection of the environment or to free trade, but also to the protection of the individual. This means that they do embody material values, albeit not necessarily those of the classic canon of constitutionalism.

The upshot is either that the international legal order does not possess a full constitution in the narrowest, legitimist sense or that its constitution suffers from some legitimacy deficiencies.

\subsection{Visualization as a loosely knit global constitutional network}

All in all, considering both international and national law together, we can discern fragmentary constitutional law elements at various levels of governance, in part relating only to specific sectors (e.g. human rights law or trade law). We might visualize these elements as situated both 'horizontally' (sectorally) and 'vertically' (encompassing both the international and the national level). The constitutional elements at the various levels and in the various sectors may complement and support each other. I call this criss-cross a 'constitutional network'. The term 'network', which is currently in vogue in various disciplines, is used here to describe relationships and interaction of norms and of their users. ${ }^{\mathrm{II} 4}$ The network picture graphically describes

\footnotetext{
I I 2. See E. Stein, 'International Integration and Democracy: No Love at First Sight', (200I) 95 AJIL 489-534, on democracy-legitimacy deficits in the World Health Organization (WHO), the WTO, the North American Free Trade Agreement (NAFTA), and the EU.

II3. See, for the WTO, Hilf and Benedek, supra note 87, at 267-70; for the UN, Cardoso Report, supra note 67, passim.

I I4. The notion of a 'constitutional network' does not describe an institutional design such as a 'policy network' (see J. M. Witte, W. H. Reinicke, and T. Benner, 'Beyond Multilateralism: Global Public Policy Networks', (2000) 7 Internationale Politik und Gesellschaft I 76-88); or 'transgovernmental networks' (as in K. Raustiala, 'The Architecture of International Cooperation: Transgovernmental Networks and the Future of International Law', (2002) 43 Virginia Journal of International Law I-92; A.-M. Slaughter, A New World Order (2004), esp. at 2I3-24), or a 'public-private network' as a bridge between the public and the private sector.
} 
relationships on an ideal scale between a horizontal/loose/market-like structure and a hierarchical/institutionalized/state-like one. The construction of a transnational constitutional network, in which the relevant norms cannot be aligned in an abstract hierarchy, has at least one important legal consequence: the resolution of eventual conflicts between international and national constitutional law requires a balancing of interests in concrete cases.

\section{Anti-Constitutional trends}

The constitutionalist analysis of the international legal order would be incomplete if it left out the antagonist trends which are visible in international law.

\section{I. Fragmentation}

First of all, many observers perceive the flourishing of sectoral regimes, such as international environmental law, international trade law, or international criminal law, which is accompanied by a proliferation of specialized courts, as a threat to the unity of international law. The constitutionalist reconstruction of international law is often deemed to react first and foremost to this fragmentation. ${ }^{\text {II }}$

Fragmentation is certainly not a problem in itself. ${ }^{I 16}$ Legal problems (which should, however, not be exaggerated) might be caused by contradictions, incongruities, and conflicts of competencies which may stem from fragmentation. However, a recent close examination of the structural developments in the different branches of international law has revealed that the existing body of international law is far from fragmented. It should rather be characterized as 'unity in diversity', or 'flexible diversity'. ${ }^{\text {II7 }}$ Actual contradictions and incompatibilities have so far occurred extremely rarely.

The existing and potentially increasing diversity might, as a matter of fact, render implausible the existence of a viable, single, overarching international constitution. ${ }^{\text {I18 }}$ However, even sectoral constitutions, each of which display more or less typically constitutional features, might be conceived as partial constitutions. A small problem is that the idea of partial constitutions runs counter to traditional constitutional theory and is rejected by some as an improper dilution of the term constitution. This rejection is based on the assumption that a crucial feature of a constitution is its totality. Indeed, the enlightenment quest for constitutional codification did not primarily seek the mere writtenness of the constitution, but sought to plan and order the edifice of government in one single document. Herein was expressed the 'conscious will to determine the political fate [of a community] in a

\footnotetext{
I I 5. Some scholars have advanced the idea of constitutionalism as a bulwark against fragmentation, 'as a promise that there is some system in all the madness'. Cf. Klabbers, supra note 82, at 49.

II6. Aptly putting into perspective these 'threats' are M. Koskenniemi and P. Leino, 'Fragmentation of International Law? Postmodern Anxieties', (2002) I 5 LJIL 533 et seq.

I I 7. R. Hofmann, 'Concluding Remarks', in A. Zimmermann and R. Hofmann (eds.), Unity and Diversity in International Law (2006), 49I.

I I 8. C. Walter, 'Constitutionalizing (Inter)national Governance - Possibilities for and Limits to the Development of an International Constitutional Law', (200I) 44 German Yearbook of International Law I 70, at I9I-6.
} 
uniform fashion'. ${ }^{\text {II9 }}$ The demand for a 'constitution in the sense of planned order and unity of the state ${ }^{\mathrm{I} 20}$ was a reaction to the multiple, decentralized, and overlapping units of government in the Middle Ages. One of the driving forces of constitutionalism was consequently the 'idea that starting from one centre, the uniform State should receive its basic design'. ${ }^{\text {I2 I }}$

However, today even state constitutions have, due to globalization and multilevel government, lost their capacity to regulate the totality of political activity (as pointed out in section I). Consequently, partial constitutions are no longer an anomaly (if they ever were in political reality). And although fragmentation cannot be stopped by evoking a nebulous constitutional paradigm, that approach might encourage rather than hinder the development of rules of conflict between the various and diverse subsystems. And this is what is needed in practical terms.

\subsection{Softening of international law}

The second anti-constitutionalist trend is the softening of international law. Instead of creating formal, compulsory hard law, governments increasingly rely on soft law. ${ }^{\mathrm{I22}}$ Soft law is not as such legally binding, but a commitment in the grey zone between law and politics. ${ }^{\text {I23 }}$ For states, soft rules have the advantage that they are quicker and easier to agree on, precisely because of their reduced bindingness. In a constitutionalist perspective, soft legalization is laudable to the extent that it allows a host of non-state actors to intervene and to act as co-law makers. ${ }^{124}$ Moreover, it may pave the way to hard commitments even on the level of international constitutional law: the Helsinki Final Act of I975, with its principles of human rights and democracy, ${ }^{\mathrm{I} 25}$ is the most pertinent example of success in that direction. On the other hand, soft law is anti-constitutional because it may undermine the normative power of law as such. ${ }^{\mathrm{I} 26}$ Most importantly, soft law leaves the states' sovereignty largely intact and thus fails to fulfil the core constitutional function of constraining the most powerful actors.

Some observers may doubt that this softening runs counter to the idea of constitutionalism. In fact, a similar softening tendency can be observed on the national

I I9. H. Heller, Staatslehre (I963 [I934]), 270 (author's translation, emphasis added).

I20. Ibid.

I 2 I. G. Jellinek, Allgemeine Staatslehre (I9I4), at 52 I (author's translation, emphasis added).

122. See in scholarly works, e.g., D. Shelton (ed.), Commitment and Compliance: The Role of Non-Binding Norms in the International Legal System (2000); J. Marquier, Soft Law: Das Beispiel des OSZE-Prozesses - Ein Beitrag zur völkerrechtlichen Rechtsquellenlehre (2003). See, e.g., the International Code of Conduct against Ballistic Missile Proliferation (ICOC) of 26 November 2002 with currently Iog subscribing states, available at http://www.minbuza.nl/default.asp?CMS_ITEM=MBZ460I66 (last visited I June 2004).

I23. But see K. W. Abbott and D. Snidal, 'Hard and Soft Law in International Governance', (2000) 54 International Organization 42 I, distinguishing 'soft' from 'hard' law along the parameters of obligation, precision, and delegation, which means that there is a sliding scale between harder and softer norms.

I24. See, e.g., the Wolfsberg Statement on the Suppression of the Financing of Terrorism of January 2002, issued by the so-called Wolfsberg group of leading international banks (available at http://www.wolfsbergprinciples.com/standards.html (last visited I June 2004)). See also supra section 4.6. on non-state actors.

125. Final Act of I August 1975, Basket I, Questions relating to Security in Europe: Declaration of Principles Guiding Relations between Participating States, Principle VII on human rights and fundamental freedoms, available at http://www.osce.org/docs/english/I990-I999/summits/helfa75e.htm (last visited I June 2004).

I 26. See for a classic critique P. Weil, 'Towards Relative Normativity in International Law?', (I 983) 77 AJIL 4I3-42 (orig. 'Vers une normativité relative?', (I983) 86 Revue générale de droit international public 5). 
plane. Modern state constitutions tend to be overloaded with non-justiciable, aspirational, and hortatory articles. Overall, domestic law is softened by a proliferation of voluntary non-binding agreements between national authorities and industry, codes of conduct, and the like. On the domestic level, that softening might indicate a strong and mature normative order. In mature societies, not all relations need to be governed by law, but some may be left to social discourse and informal commitments. ${ }^{\text {I27 }}$ However, it seems as if, at the international level, the softening must rather be interpreted as a sign of weakness of the normative order (lack of consensus, reluctance to give up authority and control). The global environment and policy domains appear less secure and less transparent than the domestic environment, and therefore seem to be in greater need of hard law to provide the necessary security and transparency.

\subsection{US-American hegemony}

The third anti-constitutionalist trend lies in the current sole superpower's activities on the borderline of international legality, notably in the fields of state jurisdiction, international criminal law, human rights protection, treaty application, and the use of force. ${ }^{\mathrm{I} 28}$ First, the United States exercises extraterritorial jurisdiction both in criminal and civil law matters in an exorbitant fashion. ${ }^{29}$ At the same time, the United States prevents the exercise of universal jurisdiction by other states, for example Belgium..$^{\mathrm{I}{ }^{\circ}}$ On the other hand, when it comes to restricting (not extending) US activity, US jurisdiction is denied: US constitutional guarantees were long held inapplicable to Taliban and al Qaeda combatants who have been detained since $200 \mathrm{I}$ in Guantánamo Bay ${ }^{\mathrm{I}}{ }^{\mathrm{I}}$ - although this territory is under 'complete jurisdiction and control' of the United States by virtue of the I903 Cuban-US Treaty. ${ }^{\text {I22 }}$ The United States refuses consistently to ratify world-order treaties, such as the Kyoto Protocol on Climate Change. Moreover, it actively undermines the ICC. The obstruction policy comprises bilateral immunity agreements (BIAs), ${ }^{\mathrm{I} 3}$ a UN guarantee of immunity to non-member states' soldiers participating in UN peacekeeping activities, ${ }^{134}$ and

I27. Shelton, supra note I22, at I2.

I28. See in detail A. Peters, 'The Growth of International Law between Globalization and the Great Power', (2003) 8 Austrian Review of International and European Law I09-39.

I29. For example, jurisdiction is claimed over European firms which seek to trade with Cuba. Cuban Liberty and Democratic Solidarity (Libertad) Act of I996 (Helms Burton Act), P.L. I04-I4, available at http://usinfo.state.gov/regional/ar/us-cuba/libertad.htm (last visited I Sept. 2005).

I30. Universal Jurisdiction Rejection Act of 2003 (referred to the House Committee on International Relations on 9 May 2003 (H.R. 2050)), available at http://thomas.loc.gov/cgi-bin/query/z?cro8:H.R.2050 (last visited 27 May 2004).

I3I. Judicial review denied by Al Odah v. US (consolidated with Rasul v. Bush), Judgment of I I March 2003 , US Ct. of App. DC Circ.; but see Rasul et al. v. Bush, I24 S.Ct. 2686 (2004), granting habeas corpus review.

I32. Agreement between the United States and Cuba for the Lease of Lands for Coaling and Naval Stations of 23 February I903, available at http://www.yale.edu/lawweb/avalon/diplomacy/cuba/cubaoo2.htm (last visited 27 May 2004).

I33. The exact number of BIAs (most of which were concluded under pressure) actually in force is currently not verifiable. The US State Department reports over 90 (signed) agreements. In some states a BIA is concluded as an executive agreement which does not require ratification. Of the 90 states, $4 \mathrm{I}$ are ICC state parties. See 'Status of US Bilateral Immunity Agreements', available at http://www.iccnow.org/documents/USandICC/BIAs.html (last visited 30 March 2005).

I34. UN Doc. S/RES/I 422 (2002), prolonged for one year until 30 June 2004 by UN Doc. S/RES/I 487 (2003). These Security Council resolutions were adopted pursuant to the US threat not to prolong the deployment of its forces in the peacekeeping mission in Bosnia-Herzegovina. 
national legislation explicitly prohibiting any co-operation with the ICC. ${ }^{\text {I35 In the }}$ field of human rights policy, the United States conditions financial and military aid on recipient states' human rights commitments in line with US guidelines, while subjecting itself to only a handful of international human rights instruments. ${ }^{136}$ In those few cases, the United States makes ample use of reservations, and declares the international instruments to be non-self-executing in the US courts. Finally, the US doctrine of pre-emptive strikes does not appear to be covered by Article 5I of the UN Charter. The US military attack on Iraq in spring 2003 was justified neither by a (revived) Security Council mandate nor by self-defence and was thus illegal.

The US posture of international law exceptionalism threatens international constitutional principles, namely the prohibition of the use of force and the principle of sovereign equality of states. ${ }^{\text {I37 }}$ Overall, the current factual US hegemony does not correspond to the constitutional idea of checks and balances which might on the international plane be a substitute for the 'balance of powers'. This observation does not mean that the East-West 'balance' until I 989 strengthened international law quite the contrary. Obviously, global checks and balances must be more subtle and must encompass an institutional equilibrium. Finally and to avoid misunderstandings, it is of course not claimed here that a world without the United States would be better or more constitutionalized. The point made here is only that unequal rights and unlimited powers run directly counter to the idea of an international constitution.

\section{TOWARDS A CONSTITUTIONALIST RECONSTRUCTION OF INTERNATIONAL LAW}

The constitutionalist reading of current international law is to some extent an academic artefact. It has a creative moment, simply because it lays emphasis on certain characteristics of international law. But such an intellectual construct is nothing unusual in legal practice. If we accept the hermeneutic premise that a naked meaning of a text, independent of the reader, does not exist, then the reconstruction of some portions of international law as international constitutional law is just an ordinary hermeneutic exercise. It is no distortion of norms which are 'objectively' something else, but a legitimate form of interpretation. It is no mere deduction from wishful thinking, but induced by manifold general developments in international law which have been discussed in sections 4 and 5 .

This gaze at international law and related state behaviour through constitutionalist spectacles has revealed a mixed picture. On the one hand, the legal landscape is severely marred by important anti-constitutionalist trends, notably by US hegemony.

\footnotetext{
I35. American Service Members' Protection Act of 2002 (ASPA), entry into force 2 August 2002, Sec. 2002 and 2004 (repr. in (2002) 27 HRLJ 275).

I36. ICCPR of I966 (ratified in I992, but not the optional protocol on individual communications); CERD of I966 (ratified by the United States in I994); CAT of I 984 (ratification in 1994 and acceptance of individual communications to the Committee (under Art. 2I CAT)); Genocide Convention of I948 (ratified by the United States in I988).

I37. See on sovereign equality most usefully B. Fassbender, 'Sovereignty and Constitutionalism in International Law', in N. Walker (ed.), Sovereignty in Transition (2003), I I5-43.
} 
On the other hand, some formal properties of constitutional law are present, the typically constitutional functions are fulfilled, and some universal values are identifiable within international law. This means that - on a descriptive level - it is not patently false to qualify some international norms and structures as a 'constitutional' order. However, the question remains whether this qualification is, on a prescriptive level, useful.

\section{8.r. Some legal (and policy) consequences}

So the ultimate question is which hard legal consequences and which policy effects the image of a 'constitutional network' might have. One of the functions of the paradigm is to serve as a guideline for the interpretation of textually open international norms. To give but one example, a constitutionalist Vorverständnis supports a restrictive attitude towards reservations to human rights covenants, notably if they curtail the respective control mechanisms. In a constitutionalist perspective, such reservations are presumably incompatible with the object and purpose of the treaty in terms of Article I9(c) of the VCLT. ${ }^{138}$

Second, the constitutionalist paradigm may influence the process of law making by the relevant political actors: constitutionalists welcome the proliferation of international courts, tribunals and arbitral bodies, and the strengthening of judicial review as a promising step towards further implementation of an international rule of law. ${ }^{\text {I39 }}$

Or, to give another example, constitutionalist arguments can inform critique directed at the lack of representativeness of the Security Council, they can confirm the existence of legal boundaries of that organ's (in)action, and they suggest that the ICJ develop its role as an 'international constitutional court' by reviewing the Security Council. ${ }^{\mathrm{I} 0}$ Notably the International Criminal Tribunal for the former Yugoslavia (ICTY) has, in the Tadić case, analysed the Security Council's powers in a constitutionalist perspective. ${ }^{\text {I4I }}$

Third, a constitutionalist outlook helps to unveil shocking failures of international institutions to implement the ideals of good governance, such as in the UN-directed territorial administration of Bosnia and Herzegovina. ${ }^{\mathrm{I}}{ }^{2}$

I38. See for the full argument A. Peters, 'International Dispute Settlement: A Network of Cooperational Duties', (2003) I4 EJIL I, at 2O-I. Another example of a constitutionalist reading of treaty clauses on judicial control is the Inter-American Court of Human Rights Case no. 54, Ivcher Bronstein - Competencia, paras. 32-55; Case no. 55, Caso del Tribunal Constitutional, paras. 3I-54; both judgments of 24 September I999, available at http://wwwi.umn.edu/humanrts/iachr/C/54-ing.html and http://wwwi.umn.edu/humanrts/iachr/C/55ing.html (last visited 26 May 2004). Here the Court held that withdrawal from submission to jurisdiction is only possible by denouncing the treaty as a whole. The Court thereby transformed the optional jurisdictional clause into a quasi-compulsory one.

I39. See on this issue G. Watson, 'Constitutionalism, Judicial Review, and the World Court', (I993) 34 Harvard International Law Journal I-45; J. Klabbers, 'Straddling Law and Politics: Judicial Review in International Law', in R. MacDonald and D. M. Johnston (eds.), Towards World Constitutionalism (2005), 809.

I40. See Fassbender, supra note 95, at 309-I5; E. de Wet, The Chapter VII Powers of the United Nations Security Council (2004), esp. at 372-5. In this context, the constitutionalist approach to international organizations meets the more general international constitutionalism.

I4I. Prosecutor v. Duško Tadić, Case No. IT-94-I-AR72, Decision on the Defence Motion for Interlocutory Appeal on Jurisdiction of 2 October I995, (I995) I6 Human Rights Law Journal, esp. paras. 26-8.

I42. G. Knaus and F. Martin, 'Lessons from Bosnia and Herzegovina: Travails of the European Raj', (2003) I4 Journal of Democracy 60-74. 
Finally, the constitutional reconstruction of parts of international law as constitutional law has consequences for its ranking in relation to national law. Those norms which can reasonably be qualified as having a constitutional quality may not be summarily discarded in the event of a conflict with domestic constitutional law. ${ }^{\text {I43 }}$

On the other hand, and this is important, the constitutionalist perspective (which has been recast in this paper in order to strengthen international law) can be instrumentalized by international-law nihilists. Notably a group of US lawyers has begun to use the notion of global constitutionalism in a novel way, mostly with the intention of criticism. ${ }^{\mathrm{I} 4}$ In that debate, 'global constitutionalism' appears to be associated with the fact that the entire international legal order has the (traditionally constitutional) function of containment. ${ }^{\text {I45 }}$ In this perspective, international law makes a kind of constitutional claim when claiming precedence over conflicting domestic law. This claim is currently more or less openly rejected by some scholars who doubt that states (concretely, the United States) should obey international law (as a whole). (This is actually the background to Jed Rubenfeld's proposition that 'American constitutionalism' is based on the idea of containment by domestic law only, and not by international law. ${ }^{\mathrm{I} 6}$ ) Their argument is that nations are bound by international law only if it is legitimate. ${ }^{147}$ It is not surprising that this quest has been formulated only recently. It is a consequence of the new global political constellation (the emergence of a 'New World Order' with the expectation of a global spread of democracy and rule of law after I989), and a reaction to the fact that international law has become stronger, denser, more important, and thus more 'intrusive' on national politics. The kernel of truth in the proposition of the illegitimacy of international law is that the 'old' legitimacy of international law, flowing from the will and consent of sovereign states, no longer satisfies political actors and citizens. What is needed are 'new' types of legitimacy according to 'constitutional' standards. This is indeed what global constitutionalism is about.

\subsection{Objections to a constitutionalist reading of international law}

Objections to the constitutionalist reading relate not only to the legal soundness of the reconstruction, but also to arguably negative policy effects, while both levels of argument cannot readily be separated.

One reproach is that international law lacks the 'symbolic-aesthetic dimension' which is inherent in national (constitutional) law. ${ }^{\mathrm{I} 48}$ From this perspective,

\footnotetext{
I43. See also supra section 6.5. on the network picture.

I44. Cf. E. A. Young, 'The Trouble with Global Constitutionalism',(2003) 38 Texas International Law Journal $527-45$.

I45. 'Global constitutionalism, which is an awfully vague and possibly sinister term ... [means] that international norms are increasingly called upon to play the role that constitutional principles play in the domestic legal order'. Ibid., at 528.

I46. Rubenfeld, supra note I4.

I 47. See, e.g., J. R. Bolton, arguing that international law is not (democratically) legitimate and therefore not really law, which means that the United States is not legally bound by it (J. R. Bolton, "Is There Really "Law" in International Affairs?', (2000) Io Transnational Law and Contemporary Problems I et seq.). See on the other hand M. Kumm for 'constitutionalist' arguments in favour of the legitimacy and thus of the bindingness of international law (M. Kumm, 'The Legitimacy of International Law: A Constitutionalist Framework of Analysis', (2004) I5 EJIL 907-3I).

I48. U. Haltern, 'Internationales Verfassungsrecht', (2003) I 28 Archiv des öffentlichen Rechts 5 I I-56.
} 
constitutions have the prime function of storing the meaning of a political community. They embody revolutionary ideas not in an abstract fashion, but by (physical) sacrifice. Consequently, a constitution is genuinely 'owned' by a people mainly because its meaning is transported by the sacrifice made for it. ${ }^{\mathrm{I} 9}{ }^{\text {Because all this is }}$ lacking on the international plane, the idea of international constitutional law is so the argument goes - a sham. However, this criticism appears to suffer from a gender bias ${ }^{150}$ and risks overstating the importance of irrational and mythological foundations of constitutional law. For example, the German constitution enjoys a great reputation among German citizens, although nobody was sacrificed for it in a physical sense in a war or a revolution.

Another criticism is that the constitutionalist reconstruction fraudulently creates the illusion of legitimacy of global governance. Constitutionalist language abuses the highly value-laden term 'constitutionalism' in order to draw profit from its positive connotations and to dignify the international legal order by it. However, the danger that constitutionalism is misunderstood 'as a mechanism that can instantly bestow legitimacy'51 does not seem very real. International and constitutional lawyers are sufficiently critical to realize that 'constitutionalism' is not a readymade answer, but - on the contrary - a perspective which might help to ask the right questions.

Another important objection is that international law must content itself with a more or less 'symbolic constitutionalization'. ${ }^{152}$ The gist of this criticism is that the constitutionalist reading of international law is not grounded in and backed by a real common political will and corresponding power structures and sanctions on the international level which would allow the enforcement of the international constitution. The constitutionalist reading is too idealistic and does not adequately reflect the realist calculus of governments. In the event of a problem or conflict, any constitutionalist attitude will be given up, says this critique. ${ }^{\text {I53 }}$ For instance, (Western) governments do not advocate universal human rights protection because they believe that it is a good thing, but because they are exposed to internal pressure from their constituencies to observe human rights standards and simply want to prevent other states from having a competitive advantage by not being restricted by human rights concerns. Likewise, the United Nations and other international organizations are for most member states only a means for realizing their national interests. ${ }^{154}$ However, constitutionalism is not dependent on moral attitudes which governments may or may not share. Constitutionalism may, in an epoch of interdependence, further national, economic, and political interests at least in the long run, because national and 'public international interests' tend to converge more and more. Moreover, international constitutionalism has, as was pointed out at the beginning of this article, both descriptive and prescriptive elements. It does not

\footnotetext{
I49. Ibid., at 533-4, drawing on B. Anderson, Imagined Communities (I983).

I50. Compare generally H. Charlesworth and C. Chinkin, The Boundaries of International Law (2000), at I8-22.

I5I. Klabbers, supra note 82, at 48.

I52. M. Neves, Symbolische Konstitutionalisierung (I998).

I53. Kälin, supra note I07, at 47.

I54. Ibid., at 49.
} 
merely claim to describe some features of the status quo of international relations, but seeks to provide arguments for their further development in a specific direction. It is therefore by definition 'idealist'.

This leads to another objection which asserts that constitutionalism is too apolitical, and an unrealistic 'promise of the end of politics'. ${ }^{155}$ However, law and politics should not be viewed as distinct realms, but rather as structurally coupled systems. ${ }^{\text {I5 }} 6$ Law is the product of political activity, which has been fixed in order to organize and limit (other) political action. In particular, constitutional law has traditionally been characterized as a branch of law which is very close to politics. ${ }^{157}$ In consequence, constitutionalism can, as in this paper, be conceived as a political, not an apolitical, project (although it does suggest that there is a sphere 'above' everyday politics).

Another objection is that global constitutionalism is a palliative which serves to obscure the elitist and aristocratic structure of international society and prevents 'revolutionary social change'. ${ }^{158}$ This objection reminds one of the classic socialistMarxist critique of any type of liberal reform strategy. Without entering into this old debate, it is readily admitted here that the constitutionalist approach indeed implies that (international) law should be used as an instrument of evolutionary, not revolutionary, change. The basic premise of this approach is that gradual reforms are generally preferable to revolutionary ruptures in the course of which there is a risk of the individual rights of the living being discarded, with the promise of a better future for coming generations.

A final and probably crucial concern is that the concept of international constitutionalism is too vague and indeterminate. This may be detrimental on various levels. First, there is the danger that reliance on constitutionalism is actually counterproductive because it may serve as a palliative and may postpone rather than encourage concrete debates on concrete problems, such as decision-making in the WTO, the composition of the UN Security Council, or how national parliaments can liaise with the United Nations. Another aspect of the indeterminacy of the concept is its malleability in the service of all kinds of political projects. We have seen that the term is currently being usurped by US scholars with the intention of undermining the authority of international law as a whole. And finally, if all law is somehow 'constitutionalized' and becomes more or less 'constitutional' or constitutionally infused, then nothing is constitutional. It would therefore not be helpful to make constitutionalism an absolute. Coming back to Wolfgang Friedman, it appears plausible that patterns of coexistence and co-operation persist even in a generally more constitutionalized world order.

\footnotetext{
I55. Klabbers, supra note 82, at 47.

I56. N. Luhmann, Das Recht der Gesellschaft (1993), at 407-39.

I 57. See, e.g., J. Isensee, 'Verfassungsrecht als “politisches Recht”, in J. Isensee and P. Kirchhof (eds.), Handbuch des Staatsrechts der Bundesrepublik Deutschland, Vol. VII (I992), I03.

I58. P. Allott, 'The Emerging International Aristocracy',(2002) 35 New York University Journal of International Law and Politics 308, at 336. Allott continues, 'The consoling Kantian myth that the republicanising of national constitutions will naturally produce a constitutionalising of international society, a patchwork cosmopolis, seems more improbable than ever. The UN Charter, an illusionary written constitution of international society, was and is merely the groundwork of an international oligarchy of oligarchies'.
} 


\subsection{Prospects and research agenda}

Despite the problematic aspects mentioned, which deserve and compel further scrutiny, it is here suggested that the constitutionalist reconstruction of international law merits further exploration because its benefits might outweigh the dangers. First of all, it must be repeated that numerous constitutionalist stories are currently being told in international legal scholarship. A single, uniform, consented constitutionalist approach does not exist.

The constitutionalist reading, as suggested here, in no way implies the quest for a world state. The idea is not to create a global, centralized government, but to constitutionalize global (poly-archic and multi-level) governance, ${ }^{159}$ as defined above.

Second, the constitutionalist approach to international law may help to prevent uncontrolled deformalization of international law. ${ }^{160}$ 'Deformalization' is what Martti Koskenniemi ${ }^{16 \mathrm{I}}$ and others have called the resort to some 'higher' legitimacy arguments in opposition to and in violation of international legality, as, for example, in the Kosovo crisis. ${ }^{162}$ Although constitutionalism is a value-loaded concept, it is nevertheless a legal approach in which consideration for the rule of law in a formal sense, legal stability, and predictability play a part, and which acknowledges that legality itself can engender a type of legitimacy. ${ }^{163}$ Seen in this light, constitutionalism is a juridical alternative to moralizing tout court.

Most importantly, the constitutionalist reading of the current international legal process appears to have a healthy critical potential. Because the idea of a constitution is associated with the quest for a legitimate one, the constitutionalist reconstruction provokes the pressing question of legitimacy of global governance. In consequence, the constitutionalist reconstruction of international law may help rather than block the revelation of existing legitimacy deficiencies in this body of law, which can obviously no longer rely on state sovereignty and consent alone. On the other hand, the constitutionalist reading should help to overcome statist expectations. It should and could clarify the fact that legitimacy (however understood) of norms and of political rule does not depend on exactly state-like structures of government or governance. ${ }^{\mathrm{I} 64}$ Ultimately, the constitutionalist reconstruction of international law may help to promote a multi-level, genuinely global constitutionalism, which may compensate for national constitutions' growing deficiencies.

\footnotetext{
I59. See for the notion of governance supra note 4.

I60. Habermas, supra note 2, at II5.

I6I. M. Koskenniemi, The Gentle Civilizer of Nations (2002), at 488-94; J. Petman, Human Rights and Violence: The Hope and the Memory of the New World Order (2007).

I62. The Expert Commission with R. Falk and others qualified the Kosovo intervention as illegal, but legitimate (Independent International Commission on Kosovo, The Kosovo Report: Conflict, International Response, Lessons Learned (2000), I 85-98, esp. at I86).

I63. Cf. R. von Ihering, Geist des römischen Rechts auf den verschiedenen Stufen seiner Entwicklung, Part II (I898), at 47 I: 'Die Form ist die geschworene Feindin der Willkür, die Zwillingsschwester der Freiheit. Denn die Form hält der Verlockung der Freiheit zur Zügellosigkeit das Gegengewicht, sie lenkt die Freiheitssubstanz in feste Bahnen, dass sie sich nicht zerstreue, verlaufe, sie kräftigt sie nach innen, schützt sie nach aussen. Feste Formen sind die Schule der Zucht und Ordnung und damit der Freiheit selber und eine Schutzwehr gegen äussere Angriffe - sie lassen sich nur brechen, nicht biegen.'

I64. Kumm, supra note I47, at 929.
} 